\title{
Morphometric measurements of bedrock rivers at different spatial scales and applications to geomorphological heritage research
}

\author{
Miguel Gomez-Heras ${ }^{1 *} \mathbb{D}$, Jose A. Ortega-Becerril ${ }^{1}$, Julio Garrote² ${ }^{2}$ Rafael Fort ${ }^{3}$ and Laura Lopez-Gonzalez ${ }^{4}$
}

\begin{abstract}
Morphometric characterisation is particularly relevant in the study of geomorphological heritage. 3D modelling techniques have been proven as very useful tools to recognise, characterise and valorise geomorphosites. Bedrock rivers account for one of the most outstanding aspects within geomorphological heritage due to the amount of distinctive and attractive geomorphological features associated to them and the high preservation of sculpted forms. Digital elevation models (DEMs) have made it increasingly possible to establish accurate morphometric indices and establish clearer connections between forms and processes. This paper reviews different methodologies to obtain DEMs on bedrock rivers. This review goes from DEM analysis at multiple spatial scales to introduce optical microrugosimeter as the latest technical development to facilitate micromorphometric analysis. Micromorphometric analysis opens the scope for improving the knowledge we have on trans-scale issues in bedrock rivers. Micromorphometric analysis also opens a new layer of information that enriches the public's valuation of geodiversity of geomorphosites by increasing its didactic and interpretative potential.
\end{abstract}

Keywords: Bedrock rivers, Geomorphological heritage, Non-destructive techniques, Digital elevation models, LiDAR, SfM, Photogrammetry, Microroughness

\section{Introduction: geomorphological heritage and bedrock rivers}

Geomorphological heritage is a very distinctive topic that is receiving considerable interest in the last few years among geoscientists involved in geoheritage studies (Coratza and Hoblea 2018). The progress in remote sensing technologies over the last 50 years has been central in the development of geomorphology (Wohl et al. 2017) and promoted a tool for increasingly detailed morphometric characterisation. Morphometry is indeed particularly relevant in the study of geomorphological heritage and, above all, 3D modelling techniques have been proven as very useful tools to recognise, characterise and valorise geomorphosites (Ravanel et al. 2014, 2015). The term "geomorphosite" was suggested by Panizza (2001) to refer to landforms that have acquired

\footnotetext{
*Correspondence: miguel.gomezheras@uam.es

'Department of Geology and Geochemistry, Universidad Autónoma de Madrid, 28049 Madrid, Spain

Full list of author information is available at the end of the article
}

a scientific, cultural/historical, aesthetic and/or social/economic value due to human perception or exploitation.

Morphometric characterisation at different scales is crucial for a better knowledge and valorisation of geomorphological heritage. Cayla et al. (2012) introduced the concept of "perceptive invisibility" as the lack of visibility of a geomorphosite conditioned by the scale of observation. They associated this concept to large geomorphological structures, but it could also be extrapolated to very small weathering forms whose perception and interpretation might be difficult for the observer and, at times, are essential for the understanding (and therefore valorisation) of geomorphological processes taking place at a particular location. Nonintrusive and high-resolution spatial monitoring are, as Hoblea et al. (2014) recognised, excellent tools for conservation and promotion of "neglected" geomorphological features.

Bedrock rivers are a fine example of geomorphological sites with forms of various scales. Bedrock rivers account 
for one of the most outstanding aspects within geomorphological heritage due to high preservation of sculpted forms in bedrocks (Garzón-Heydt et al. 2012). Besides playing a critical role in landscape evolution, these rivers constitute important features in protected areas, due to the amount of distinctive and attractive geomorphological features associated with them, from large-scale canyons and gorges to small-scale grooves, flutes and furrows. This is reflected, for example, in the myriad of terms in many languages associated with bedrock rivers which are not only part of scientific jargon but commonplace terms used in daily language, such as waterfall, canyon, narrow, and rapids. Furthermore, some names given to sculpted forms in bedrock rivers are rather symbolic, as for example Spanish and Italian "Giant's marmites" for potholes or "pans" and "scallops" in English. The importance of some bedrock river forms goes far beyond scientific and natural values to have a place in popular culture, as for example the large-scale Grand Canyon (Colorado River), the number one tourist destination in the USA, but also smaller features, such as Antelope Canyon, a narrow bedrock river managed by Navajo Native Americans as a tourist attraction. Waterfalls associated with bedrock rivers are among the most demanded tourist destinations, such as Iguazu waterfalls in the Argentina-Brazilian border, one of the most visited waterfalls in the world (Hudson 2013) along with Niagara Falls (USA-Canada), Victoria Falls (Zimbabwe) and Salto del Angel (Venezuela). This interaction between geomorphological components of a territory and cultural features frames in Panizza and Piacente's (2008) definition of cultural geomorphology and makes of bedrock rivers one of the most important features to be included in this term. Bedrock rivers are among the most valued features in some protected areas, such as Sobrarbe Geopark in the Pyrenees (Ortega-Becerril et al. 2017a) because their high variety of features at different scales is an added value when designing geotouristic routes.

This paper aims to review different techniques to get morphometric measurements at different scales. Building on a review of commonly-used techniques, such as LiDAR (Light Detection And Ranging) and photogrammetry, this paper intends to show the value of innovative microphotogrammetric techniques (optical rugosimeter) in contributing to the understanding and valorisation of trans-scale flow-related geomorphological processes of bedrock rivers. Bedrock rivers are a relatively poorly-understood environment in which the interpretation of features is very dependent on the scale. To demonstrate the scope of these techniques, a particularly relevant geosite within a bedrock river in central Spain (upper Manzanares) will be used. In addition, this paper shows the potential of high-resolution micromorphometric techniques as a tool for visibilisation and valorisation of small-scale erosive features in this particular geomorphosite.

\section{Bedrock rivers: morphometry and scale issues}

Quantitative morphometric aspects of bedrock rivers are of great importance. Morphometry, i.e. the measurement of forms of the ground surface is consubstantial to the birth of geomorphology as a preliminary step to interpret processes. As early as 1899, Davis (p.481) stated "all the varied forms of the lands are dependent upon (...) structure, process and time", showing that early in the development of geomorphology as a science came the realisation that only after understanding forms one can interpret them as the result of processes.

In bedrock rivers, as in other environments, morphometry is one of the main tools to discriminate forms. Yet, some of those forms resemble, but are genetically different, as for example in several features described by Richardson and Carling (2005), e.g. compound parallel-side furrows and runnels with alternating scour. Nevertheless, this variability and complexity in forms and processes is one of the main scientific values of bedrock rivers (and therefore also an asset for their geomorphological heritage status).

The relationship between morphometry and processes in bedrock rivers is considered an under-researched area, due to the patchiness and morphological discontinuity of bedrock rivers and because, echoing J.W.N. Sullivan's famous quote, "it is much easier to make measurements than to know exactly what you are measuring". Richardson and Carling (2005, p.1) stated, "the morphology of surface bedrock channels is still a relatively neglected area of research within the study of fluvial systems". Anyhow, there has been a big evolution in this research area from Wohl's (1998) and Richardson and Carling's (2005) seminal attempts to describe bedrock river forms to more recent efforts by Lamb et al. (2015), Beer et al. (2017), Velázquez et al. (2016) to derive processes from forms in this environment.

The formation and development of bedrock river features at different spatial scales are the result of a combination of extrinsic factors (such as stream hydraulics) and intrinsic bedrock factors such as lithology and heterogeneities (Wohl 1998) in combination with surface alteration processes, as for example wetting-drying cycles (Inoue et al. 2017). As Hall et al. (2012) suggested, "rock decay" encompasses energy transfer processes (a term they prefer to weathering), the influence of rock properties and product removal (erosion). As an example, Ortega-Becerril et al. (2017b) demonstrated how the balance between these factors led to variations in the generation of potholes, a typical bedrock river feature.

Geomorphologists define bedrock rivers as patchy reaches within a fluvial system (Whipple et al. 2013). Therefore, scale issues are deeply related to bedrock 
rivers by definition, as large-scale processes are often inferred from small-scale forms. A fluvial system to be considered a bedrock river must have long-term capacity to transport bedload vs. sediment supply and persistent incision (Whipple et al. 2013), and it must do so at a rate greater than sediment supply. Usually, the riverbed must be clean of sediment and have a high ratio $(>50 \%)$ of either exposed rock or a thin alluvial cover (Tinkler and Wohl 1998). This means bedrock reaches are frequently patchy and relatively short, and the incision rates are deeply dependent on the interaction between alluvial cover and erosive mobile grains (Sklar and Dietrich 2004; Inoue et al. 2014).

Much work has been done regarding the use of multiscale techniques in bedrock rivers (e.g. Springer et al. 2005; Ortega et al. 2014; Pelletier et al. 2014). Some of these models like Pelletier's et al. (2014) use the aspect ratio of potholes to predict flood sizes that would generate their optimal growth. Hence, large-scale processes are connected with small-scale measurements. Models of river flow in bedrock rivers (e.g. Venditti et al. 2014) are also a tool to understand processes at different scales. This is shown for example in the studies by Anton et al. (2015) describing how small-scale flooding can generate large-scale erosion and Beer et al. (2017) determining the importance of the spatial distribution of moving and static sediment in determining small-scale erosion, which in turn will result in gorge evolution at the landscape scale.

The complex balance of factors leading to changes in bedrock river forms counsels morphometrical characterisation at different scales to understand the response of different occurring lithologies to river flow and the relationships between erosion and weathering processes. Nonintrusive spatial monitoring can be also performed at different times as a way, not only for understanding processes, but also for assessing the influence of climatic and human impacts and consequently planning conservation strategies, which are especially relevant in bedrock rivers in protected areas. Methods like LiDAR and increasingly affordable photogrammetry are among other technical developments that have had a strong impact on the ability to collect data in geomorphology (Viles 2016). Hence, these techniques and how they have been used in recent times to understand processes at different scales in bedrock rivers are reviewed.

\section{DEMs from LiDAR in bedrock fluvial geomorphology and hydraulic modelling}

Burrough (1986) defined DEMs as the representation of the continuous variation of relief over space. DEMs have made it increasingly possible to establish accurate morphometric indices and establish clearer connections between forms and processes. The advancement in the knowledge of interactions between surface forms and geomorphological processes in rivers in the last decades led to an increasing need of having more precise and spatially continuous 3D topographical data (Lane et al. 1998).

LiDAR, which mainly includes ALS (Aerial Laser Scanning) and TLS (Terrestrial Laser Scanning), is nowadays one of the most precise systems to obtain data to build large-scale DEMs (Cavalli et al. 2008; Marks and Bates 2000). This technique is particularly useful in geoheritage, both in the phase of developing scientific knowledge of a site as well as in the interpretation and development of geotourism (Cayla 2014).

Hohenthal et al. (2011) classify LiDAR data in four main groups: ALS, ALB (airborne LiDAR bathymetry), TLS and MLS (mobile laser scanning), all of them with different characteristics in terms of spatial resolution and ability to penetrate water.

In addition to many other documented uses (Lohani and Mason 2001; Thoma et al. 2005; Carey et al. 2006; Milan et al. 2007; Alho et al. 2009a; Cook and Merwade 2009; Oguchi et al. 2013; Garrote et al. 2018), LiDAR data has proven especially useful when representing bedrock river morphology, as for example Baggs Sargood et al. (2015), Sweeney and Roering (2017) or Beer et al. (2017) pointed out.

LiDAR shows some advantages in relation to other topographic techniques. For example, ALS offer quicker data, with higher spatial density at a lower cost than traditional methods, such as theodolites and total stations (Charlton et al. 2003; Gomes-Pereira and Wicherson 1999). LiDAR advantages in comparison to other remote sensing techniques (such as aerial and satellite images) include the ability to measure elevation in surfaces covered by vegetation (Charlton et al. 2003; Gomes-Pereira and Wicherson 1999). In addition, LiDAR does not depend upon illumination condition (Baltsavias 1999a).

However, not everything is positive about LiDAR data. The variability in the characteristics of the sediments and forms in bedrock rivers can produce errors in the DEMs generated from LiDAR data (Hodgson and Bresnahan 2004; Hodgson et al. 2003). Thus, Heritage and Hetherington (2007) observed how the best precisions in the elevation data are obtained in gently sloped riverbeds, while the precision decreases significantly on riverbeds covered by pebbles and blocks because of shadowing. Another source of precision decrease is vegetation cover (Fig. 1), which has a positive correlation with errors in elevation of LiDAR data (Charlton et al. 2003; Hodgson et al. 2003). Heritage and Hetherington (2007) estimated in $0.07 \mathrm{~m}$ the error between TLS data and data obtained with theodolites 
for areas with variable vegetation cover. Other works (e.g. Hodgson and Bresnahan 2004; Baltsavias 1999b; Overton et al. 2009) have also analysed the effect on the accuracy of LiDAR data of other types of vegetation cover, density and height and its influence on laser pulses discrimination. Furthermore, as Jones et al. (2007) stated, the use of automatic techniques for filtering LiDAR data can affect significantly the identification of fluvial forms (areas without surface topographical data appear and need to be interpolated). In a bedrock environment like the strath terraces, automatic filtering of LiDAR data may reduce the quality of resulting DEMs (Reusser and Bierman 2007).

Spatial resolution of ALS data is adequate for visual recognition of typical fluvial macro-forms, such as channels, paleo-channels, pointbars, alluvial fans and levees (Aggett and Wilson 2009; Jones et al. 2007; Notebaert et al. 2009; Kasvi et al. 2012). Less work has been done in bedrock channels, with some works of Reusser and Bierman (2007) and Finnegan and Dietrich (2011) mostly on medium- and large-scale features such as strath terraces.
Cartography and interpretation of fluvial forms from ALS data is limited by different factors. Mainly, spatial density of data may limit the identification of small-scale forms (i.e. when topographical variations are very small in relation to the surrounding terrain) on DEMs created from the interpolation of ALS data (Notebaert et al. 2009). Thus, the spatial resolution and vertical error of ALS data determine the minimum size of forms that could be identified. Notebaert et al. (2009) show an example of the abovementioned when comparing fluvial forms that can be identified with two DEMs of different spatial resolution (5 and $1 \mathrm{~m}$ ), indicating how the use of shading models derived from the ALS data helps in both cases to the identification of fluvial forms (Fig. 2).

The use of LiDAR data has become widespread for hydraulic modelling, because it improves the definition of channel geometry, both in 1D studies (e.g. Aggett and Wilson 2009; Omer et al. 2003; Casas et al. 2006) and in

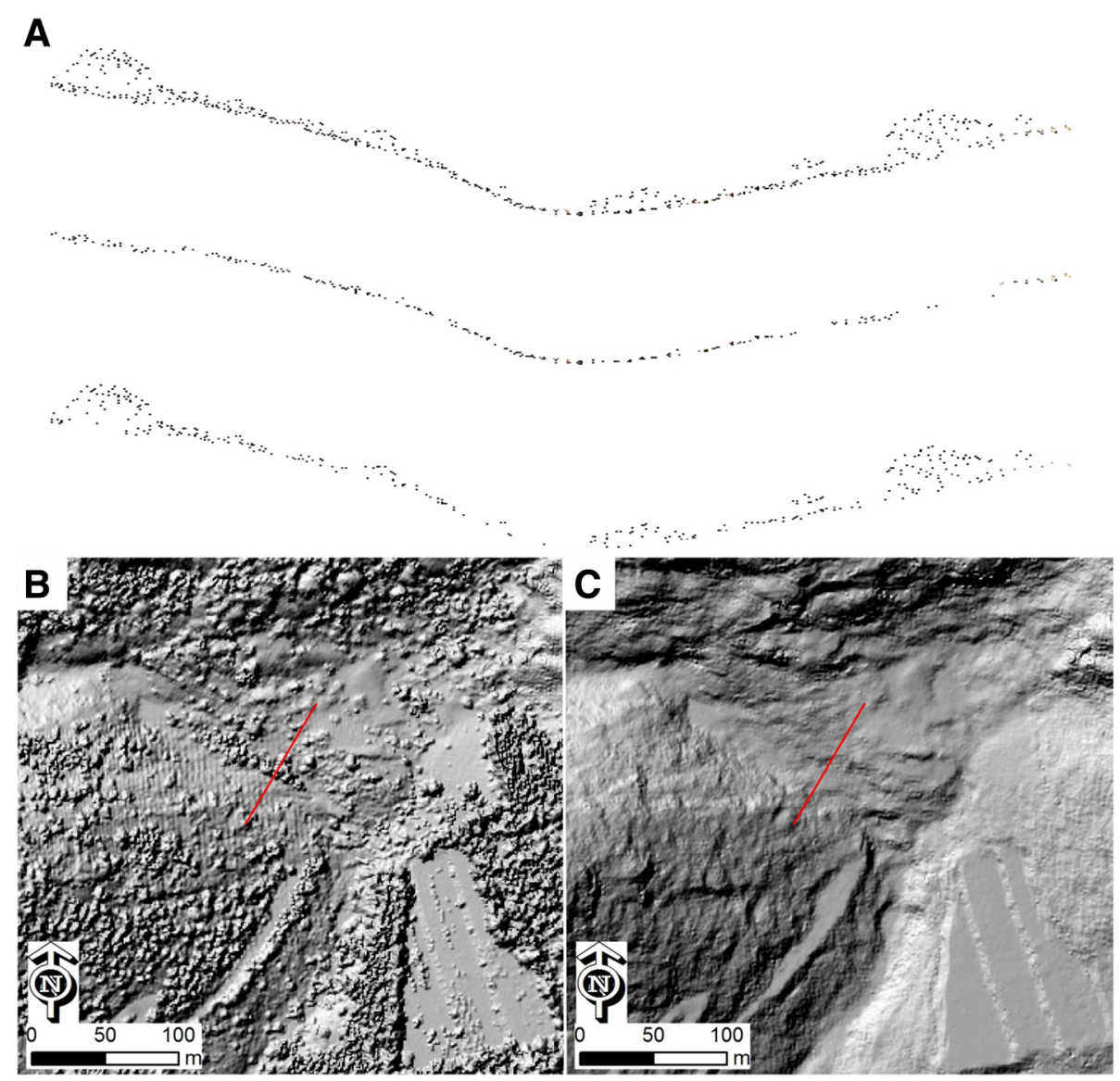

Fig. 1 Effect of vegetation cover on ALS data (National Geographic Institute, Government of Spain) corresponding to the case study area in "La Pedriza" (Madrid, Spain). a Elevation profile from ALS considering all the ALS points (up), only the points classified as terrain (middle), and only the points classified as vegetation (bottom). The number of ALS points giving information on the terrain surface decreases in the areas with more vegetation. Effect of vegetation on a DEM considering all the ALS points (b) and only the points classified as terrain surface (c). The red line corresponds to topographic profiles in (a) 


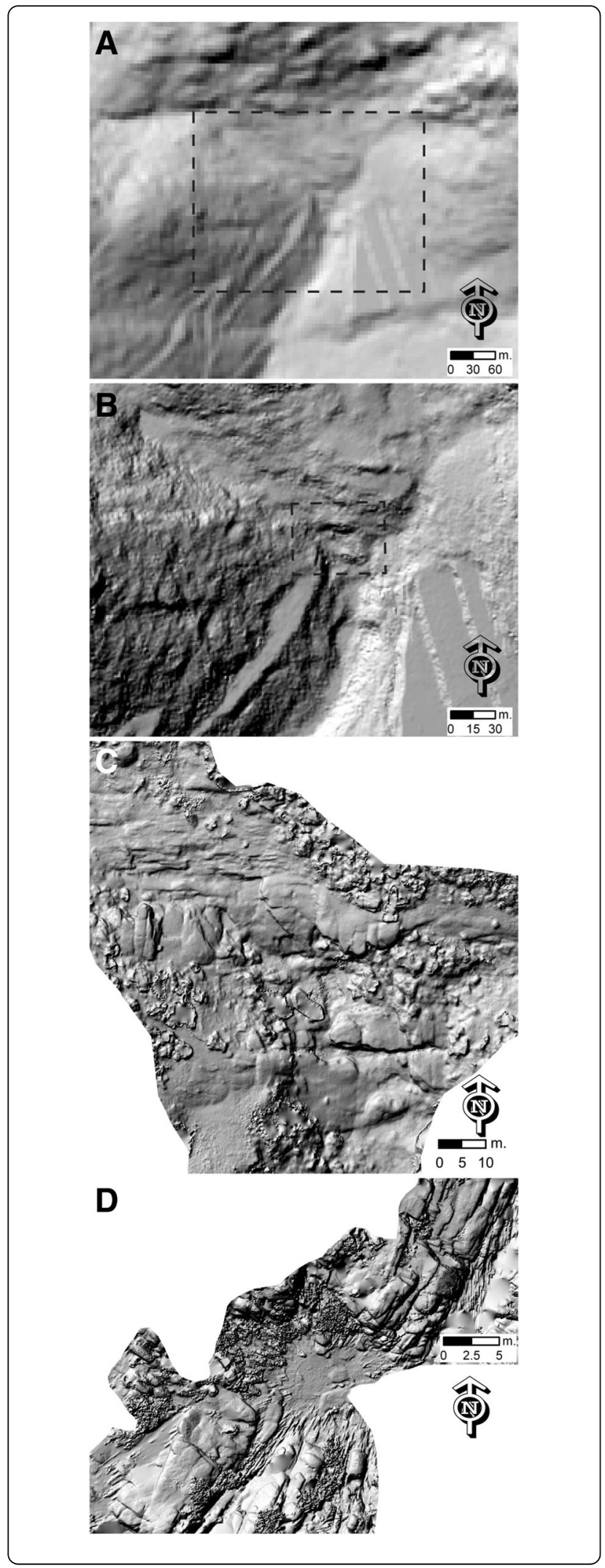

Fig. 2 Hillshade DEM obtained from ALS data, with spatial resolutions of $5 \mathrm{~m} \mathrm{(a)} \mathrm{and} 1 \mathrm{~m} \mathrm{(b)}$; detailed digital photogrammetry (c) obtained from UAV image (resolution $0.25 \mathrm{~m}$ ). a-c the case study area in "La Pedriza" (Madrid, Spain). Panels $\mathbf{b}$ and $\mathbf{c}$ are enlargements from marked areas in $\mathbf{a}$ and $\mathbf{b}$. $\mathbf{d}$ TLS data interpolated with a spatial resolution of $0.05 \mathrm{~m}$. Panel $\mathbf{d}$ is obtained from UNAVCO organisation TLS free data of an area near Prescott (Arizona, USA, http:// opentopo.sdsc.edu/datasets?id=OT.122010.26912.1\&host=ot). This sequence shows how ALS resolution does not allow identifying small-scale elements in the channel, something that can only be achieved from TLS and detailed digital photogrammetry data

2D hydraulic models (e.g. French 2003; Marks and Bates 2000; Straatsma and Baptist 2008). These LiDAR data have also been used to define terrain surface roughness, as an improvement from other, more traditional, techniques based on photo-interpretation or granulometric studies of sediment samples (Mason et al. 2003; Heritage and Milan 2009; Milan 2009). Milan (2009) shows that one of the main advantages of using LiDAR data to determine surface roughness is the ability of this data to reproduce roughness spatial variability.

The use of LiDAR has allowed significant improvement in DEM accuracy in bedrock rivers and therefore a better representation of the highly-variable topography of bed and banks in these rivers (mainly by using TLS data, and both aerial and terrestrial detailed photogrammetry). As the topography obtained in the DEM is more detailed, the effect of even small-scale features on flow diversion can be reflected in flow direction vector field maps at most scales, which leads to a more realistic reconstruction of actual flows.

The availability of ALS data to cover large terrain areas has been shown as an essential aspect for a correct mapping of flood areas on the floodplain, where topographic variations in elevation are small but they affect the flow of shallow water (French 2003). Thus, several authors have investigated the potential for the use of ALS data for flood mapping in recent years (e.g. Cook and Merwade 2009; Overton et al. 2009). One of the main conclusions obtained by authors like Cobby et al. (2003) and Cook and Merwade (2009) is that using ALS data generally implies a decrease in the extent of modelled flood zones. This is due to the increment of vertical accuracy of topographic data (which is now more capable of representing small-scale topographic variations in the floodplain). The use of a precise channel bathymetry further enhances the reduction of the modelled flood inundation area.

It is only now, when LiDAR results are more faithful to real topography, that it is possible to locate and assess fluvial process like cavitation and plucking, which are decisive in the initiation and development of typical bedrock river morphologies like potholes and grooves. Another improvement from the use of these more realistic 
surfaces is related to flow direction pattern variations and its relationship with peak flow values.

The use of TLS data meant a significant improvement for the quantification of meso- and micro-scale forms in relation to the use of traditional contact profilers, such as erosion pins or microtopographic profilers (Hodge et al. 2009a, 2009b; Wang et al. 2013), by improving spatial resolution of the data obtained. It is also, as pointed out by Entwistle and Fuller (2009), a much faster method for the characterisation of the sediment than the taking of samples and its granulometric analysis. To limit topographic noise, Hodge et al. (2009a) recommended setting spatial resolution of TLS data to centimetre scale (even when these techniques are capable of producing millimetre resolutions), with the aim that the variations in the topography are not masked by the noise existing in the data. Associated with this limit in the spatial resolution of TLS data, Alho et al. (2009b) stated that even when sediment characteristics could not allow their individual identification by TLS, it would still be possible to map variables as important as the height, length, volume and orientation of fluvial forms such as ripples and dunes.

\section{Structure from motion: A cost-effective multiscale technique}

Rock weathering and erosion operate at different temporal and spatial scales (Viles 2001). Therefore, morphometric investigation needs to be able to accommodate to different scales. As mentioned elsewhere, considering small-scale sculpted forms can give evidence of larger-scale morphological change in bedrock rivers, both large-scale features and small-scale forms to be assessed together to get the whole picture of how "energy transfer" (in the sense of Hall et al. 2012) interacts with rock properties.

Chandler and Buckley (2016) state that SfM photogrammetry can be a good technique to overcome the main challenges associated with TLS: cost, occlusions and the lack of flexibility of scale. Structure form motion photogrammetry can use photographs taken with a conventional camera, and processing may be accomplished through inexpensive (or even free) software. This contributed to the extensive use of SfM photogrammetry over TLS (Almagro 2010; Westoby et al. 2012).

Photogrammetry is a long-used technique in geology and geomorphology. Laussedat (1854) already noticed that accurate measurements could be made from multiple images taken with slight offset. From then through the increasing relevance of photogrammetry from the 1940s in mapping (e.g. Birdseye 1940; Eardley 1942) to nowadays, structure from motion (SfM) methods used in the most advanced photogrammetry software, photogrammetry has consolidated as a very suitable technique for the generation of DEMs at low cost.

"Structure from motion" (or "multi-image photogrammetry" as it is sometimes called) is the photogrammetric technique in which datasets of overlapping digital images of a feature taken from different positions are loaded into a software to obtain high-resolution 3D models (McCarthy 2014). Currently, the speed of calculation of the computers and the great development of digital cameras allows the immediate restitution of the photographed object, getting some rectified images, with actual measurements.

Multi-image photogrammetry has been used for the last 20 years in geomorphological studies (e.g. Chandler 1999; Lane 2000; Westoby et al. 2012; Saito et al. 2018) and in heritage applications, such as archaeology (e.g. Bryan and Clowes 1997; De Reu et al. 2013, 2014), cultural heritage (e.g. Lopez-Gonzalez et al. 2016; Fujii et al. 2018) and geoheritage (e.g. Fernández-Lozano and Gutiérrez-Alonso 2017; Santos et al. 2018).

The development of cameras, inertial units, UAV and smartphones in this same timespan now makes it possible to find examples of multi-image photogrammetry using large-scale images taken with UAV (e.g. Domínguez Pérez et al. 2017), as well as close-range photogrammetry (e.g. Fraser and Cronk 2009; Jordá et al. 2011; McCarthy 2014) and even smartphones (e.g. Micheletti et al. 2015).

The possibility of obtaining results with accessible low-cost equipment makes photogrammetry one of the most widespread methods to obtain DEM, especially at close-range (Almagro 2010). Photogrammetry allows obtaining DEMs of both large and small features with the same equipment (camera and software), so it can be used in its own right or as an inexpensive way of complementing more expensive LiDAR.

As precision in SfM is dependent upon scale (the closer the images are taken the more precise is the model), for small-scale features, a SfM can generate a high-accuracy point cloud at a significantly lower cost than TLS. The use of targets allows scaling, orientation and geo-referencing, which can remain relative or be made absolute through a GPS or total station.

Geo-referencing is particularly relevant when analytical data will be superimposed on the model, thus, creating a high-detail small-scale GIS (Gomez-Heras et al. 2014; Lopez-Gonzalez et al. 2016). This also allows a 4D approach, i.e. the addition of time to the three spatial dimensions $\mathrm{X}, \mathrm{Y}$ and $\mathrm{Z}$, by comparing and operating with a series of surveys obtained through time (Lopez-Gonzalez et al. 2016), as a step forward from the mere evaluation of landform changes (e.g. Lin and Oguchi 2002; Hayakawa et al. 2008). 


\section{Contribution of micromorphometry to the study of bedrock rivers and small-scale geomorphodiversity}

Up to this point, this paper has reviewed the evolution of techniques, which have been commonly used in 3D Modelling for the research and monitoring of fluvial environments (particularly bedrock rivers) and are also amply used for visualisation and valorisation of geoheritage (Cayla 2014; Ghiraldi et al. 2014; Ravanel et al. 2014, 2015).

Ortega-Becerril et al. (2017a) discussed how the assessment of the geomorphodiversity of bedrock rivers should include larger spatial scales rather than individual river reaches. Likewise, the assessment of geomorphodiversity should also include microscale because of the large variety of bedrock sculpted forms (some of them at microscale) in this environment.

This is particularly true considering the definition of geodiversity, which includes the features together with the processes that form and alter them (e.g. Dudley 2008; Németh et al. 2017). As previously discussed, microforms are key for the understanding of geomorphological processes in bedrock rivers. However, these forms remain "invisible" analogously to the sense in which Cayla et al. (2012) used this term for large geomorphological structures.

The previously reviewed techniques may allow morphological analysis up to a centimetre accuracy, but their resolution level usually does not permit morphometric analysis of sculpted forms below this scale (Fig. 3). Particularly, the previous reviewed techniques would not be practical to analyse large-scale forms at the same time than microforms, which are relevant for the scientific knowledge of geomorphological processes in bedrock rivers and also for the public understanding (and therefore

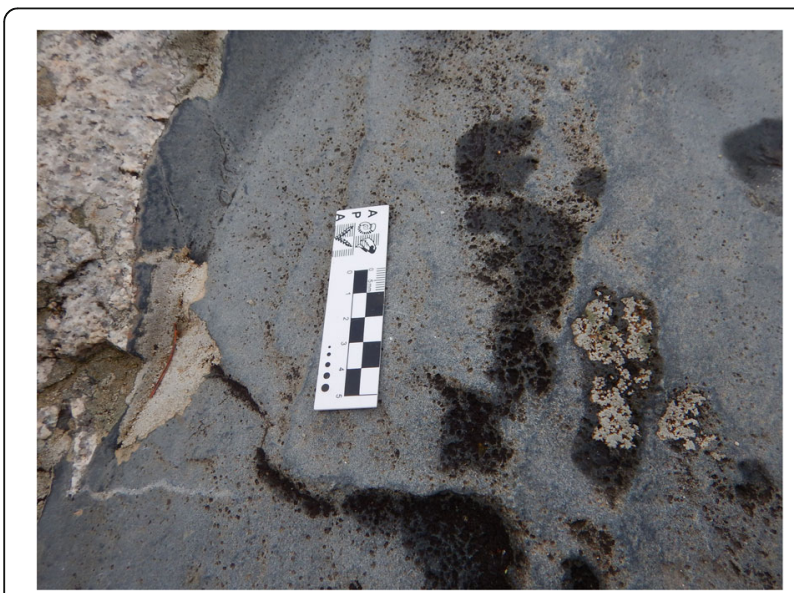

Fig. 3 Millimetre-scale pits and grooves in a microdiorite dyke. Darkcoloured area corresponds to moisture accumulated in and around pits. This is likely to cause weathering through wetting-drying cycles valorisation) of geomorphosites. For this level of detailed analysis, this paper reviews a novel application to geomorphology of a technique already used in cultural heritage: the optical rugosimeter.

Surface microroughness is one of the main controls in the initiation of weathering processes. The term "micro" in roughness refers to variations in the relief in order of magnitudes of ten of micrometres. The formation of microrelief is controlled, much like the formation of relief at larger scales, by a combination of lithological and environmental factors. In igneous rocks, compositional heterogeneity of the rocks at the mineral scale contributes to increasing surface roughness due to the different resistance to deterioration agents of each mineral (Gomez-Heras et al. 2008; Sousa and Gonçalves 2013). This is particularly relevant in coarse texture granites, which tend to have a greater roughness (Aydin et al. 2011) that increases during the process of deterioration of the rock.

Surface porosity, as a consequence of higher roughness, favours water penetration into the rock and can trigger deterioration by salt crystalisation, freezing-thawing and wetting-drying cycles. Likewise, water or wind can generate microroughness due to microturbulence and impacts of particles in suspension.

Surface microroughness can also favour surface deposits, which either can increase the deterioration process or can form a crust on its surface becoming more resistant to erosion, as is the case in the formation of carbonate or iron oxide crusts. Microroughness is also a contributing factor to the colonisation of endolithic microorganisms, helping their adherence on the surface of rocks (Etienne 2002; Bergey 2006; Prieto et al. 2006; Viles 2012).

Igneous rock porosity is mainly fissural. Microcracks develop both in the interface between rock minerals (intercrystalline porosity) or inside minerals (intracrystalline porosity), such as along crystallographic planes in biotite (López-Arce et al. 2010) and twin planes in feldspars (Vázquez et al. 2013). Moropoulou et al. (2007) defined a friability index, considering fracture density and surface roughness. Friability increases (and therefore resistance decreases) when increasing the roughness. Therefore, when a rock has high roughness, it is more prone to deterioration (Ribeiro et al. 2011). Roughness difference in igneous rocks depends on fissural anisotropy at outcrop (López-Arce et al. 2010; Sousa and Gonçalves 2013; Freire-Lista and Fort 2017) and the effects of weathering agents, such as thermal fatigue, salt crystallisation or frost action (Gomez-Heras et al. 2008; Freire-Lista et al. 2015).

The study of microroughness not only allows us to understand the process of deterioration of rocks but also allows us to provide information on weathering/erosion 
rates by different deterioration agents being influenced by the hardness of each mineralogical component of the rock. They can indicate preferential directions of erosion such as in the action of glacial polish (Dąbski 2015), and bedrock outcrops related to, fluvial water flow when abrasion, plucking and cavitation processes are frequent (Whipple et al. 2012) and recognised in the studied area (Ortega-Becerril et al. 2017b).

There are different techniques to measure microroughness: contact (profilometers) and non-contact rugosimeters (optical rugosimeters) (Grissom et al. 2000). In addition to these, it is possible to measure the roughness of the surface of the materials by means of high-resolution microscopic techniques, such as scanning electron microscopy (SEM), atomic force microscopy (AFM) and tunnelling microscopy (STM). Profilometers and optical rugosimeters have the advantage of being non-destructive and portable, while techniques such as AFM, SEM and STM have a higher resolution but they are destructive, and measures must be carried out in a laboratory at a much higher cost (Fort et al. 2013).

Profilometers have been the most common technique so far for microroughness determination in geomorphology (e.g. McCarroll 1992; Hubbard and Glasser 2005; Dąbski 2015). A fine tip crosses the surface of the object in these contact rugosimeters. Height variations of the tip moving at a controlled speed are transformed into electrical impulses that result in a profile showing surface topography.

Optical rugosimeters have been amply used in cultural heritage science (e.g. Fort et al. 2012; Vazquez-Calvo et al. 2012) and only more recently on geological heritage (e.g. Esteve et al. 2018). However, to this day, they have not been used in geomorphological analysis nor in the valorisation of geoheritage.

Optical rugosimeters (Fig. 4) share principles with multi-image photogrammetry. Three collimated white light sources incise angularly $\left(70^{\circ}\right)$ to the surface and three images are taken at $0^{\circ}, 120^{\circ}$ and $240^{\circ}$. These images are integrated automatically with photogrammetric techniques offering a 3D image of the surface. This equipment marketed as TraceIT (Fig. 5) allows measuring the surface roughness of a $5 \times 5 \mathrm{~mm}$ area with a resolution in the three directions of the $2.5 \mu \mathrm{m}$ space. The topography (roughness) of the analysed surface (25 $\mathrm{mm}^{2}$ ) is obtained by processing the results from between 500 and 1500 profiles for each of the X and Y-axes of the measured plane. The whole illumination and image acquisition system is integrated in a hand-held portable measuring unit. A fixed array of illumination and sensors facilitates repeatability, diminishing errors caused by these factors in subsequent measurements. Other sources of variability between subsequent measurements or operators would be comparable to other surveying

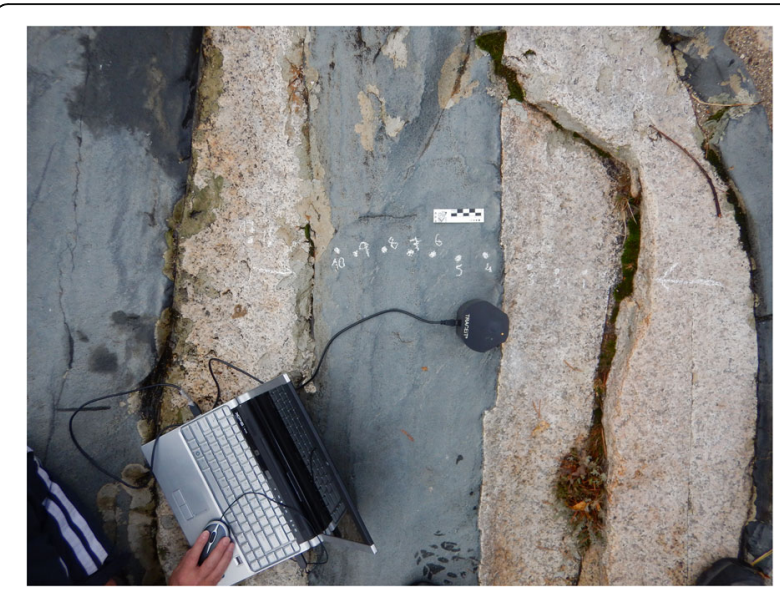

Fig. 4 Innowep TracelT optical rugosimeter. The acquisition unit (centre) contains the three collimated light beams and cameras that allow a photogrammetric reconstruction of a $5 \times 5 \mathrm{~mm}$ area. North is on the right of the image

methods and negligible, as suggested by Scott et al. (2016).

There is a great variety of parameters to quantify the roughness of a surface or its roughness profiles. McCarroll (1992) establishes roughness parameters that determine the standard deviation of the slope between the two adjacent measurement points on the surface of the rock (index $\mathrm{A}$ ), and the absolute difference between the adjacent slope values (index B), but at this time other parameters are used that allow a more visual interpretation of the results (Santos and Júlio 2013). Currently, the following parameters (see Fig. 5 for the elements in a profile) are used:

- Average roughness-Ra: average of the absolute values of deviations from the base line of the profile.

- Root-mean-squared roughness-Rq: root mean square of deviations from the base line of the profile.

- Total roughness-Rt: height between the highest and lowest point in the profile.

- Mean peak-to-valley height-Rz: sum of the five highest peaks and five lowest valleys in the profile.

- Among these parameters, $\mathrm{Rz}$ is considered the best discriminating profiles (Dąbski and Tittenbrun 2013).

\section{Case study: the upper Manzanares river as an example of multiscale geomorphosite}

A landform to be defined as a geomorphosite needs to have scientific, cultural/historical, aesthetic and/or social/economic value (Panizza 2001). The upper Manzanares river is one of the most outstanding bedrock rivers in Spain, and probably in Europe, for its relevant scientific value (particularly, due to the variety of features at different scales contributing to the understanding of 


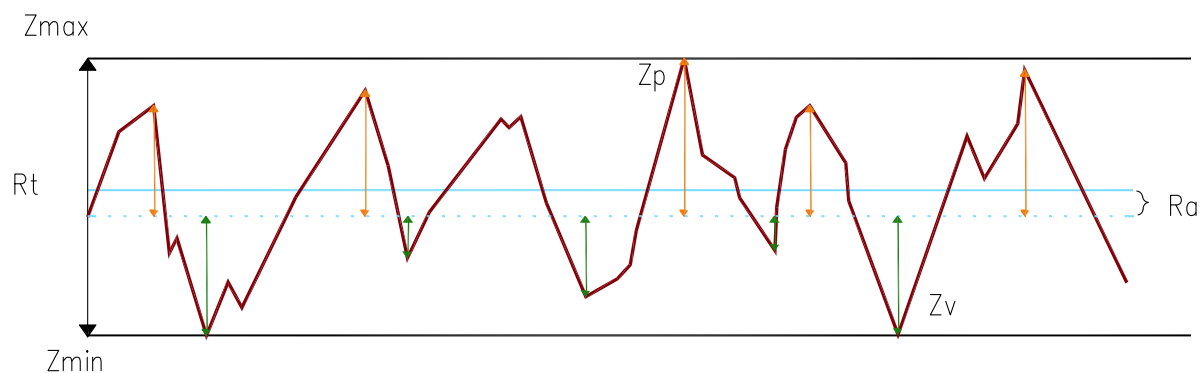

Fig. 5 Schematic view of a topographic profile showing the elements to define Ra and Rt roughness parameters. Blue dotted line: base line of the profile; Zp: height of the highest peak; Zv: deepest valley; Zmax: parallel line of the baseline that marks; Zmin: line parallel to the baseline that marks the deepest valley; brown arrows: the five highest peaks; green arrows: the five deepest valleys

bedrock river geomorphology) in addition to numerous cultural/historical values.

The upper Manzanares river is a bedrock reach located in "La Pedriza" (Fig. 6) within the Sierra de Guadarrama National Park (Madrid, Spain). La Pedriza constitutes the largest granitic outcrop in Europe, and its importance, together with the rest of the national park, is seminal for the development of geology in Spain and granite geomorphology worldwide. For example, several granite weathering forms were illustrated for the first time in this area, such as tafoni (De Prado 1864). Geomorphological studies in this area extend to nowadays (e.g. Pedraza et al. 2014), being particularly relevant to those associated with gnammas formation (e.g. Domínguez-Villar et al. 2008), weathering processes (e.g. García-Rodríguez et al. 2015, 2017) and bedrock river features (Ortega et al. 2014; Ortega-Becerril et al., 2017b).

This area is also outstanding in terms of the cultural values associated with it. La Pedriza has been part of paintings throughout history (Bernaldo de Quiros 1923;
Pena 2016) and is also important in the development in Spain of fieldwork as an educational tool in the late nineteenth century (Otero 2004). The Sierra de Guadarrama was therefore listed as a national park in 2013 because of its outstanding natural, scientific and cultural values. Under the light of its exceptional heritage status, the upper Manzanares river will be used as a case study to show the potential of an optical rugosimeter. Specifically, an area listed as a geosite (Code TMP126 in the Spanish Inventory of Places of Geological Interest-IELIG) where a series of microdioritic dikes intrude a coarse-grained Variscan leucogranite (Fig. 7).

The upper Manzanares river is a perennial river which drains an area of around $50 \mathrm{~km}^{2}$. The selected area consists of a mixed bedrock alluvial channel (10-15 m wide) that contains large boulder obstacles in-channel, a knickpoint, potholes, step-pool sections and some smooth rock platforms. The reach-scale channel gradient is 0.12 $\mathrm{m} / \mathrm{m}$. The sediment cover at the site is very scarce. Floods occur mainly in winter caused by frontal systems.

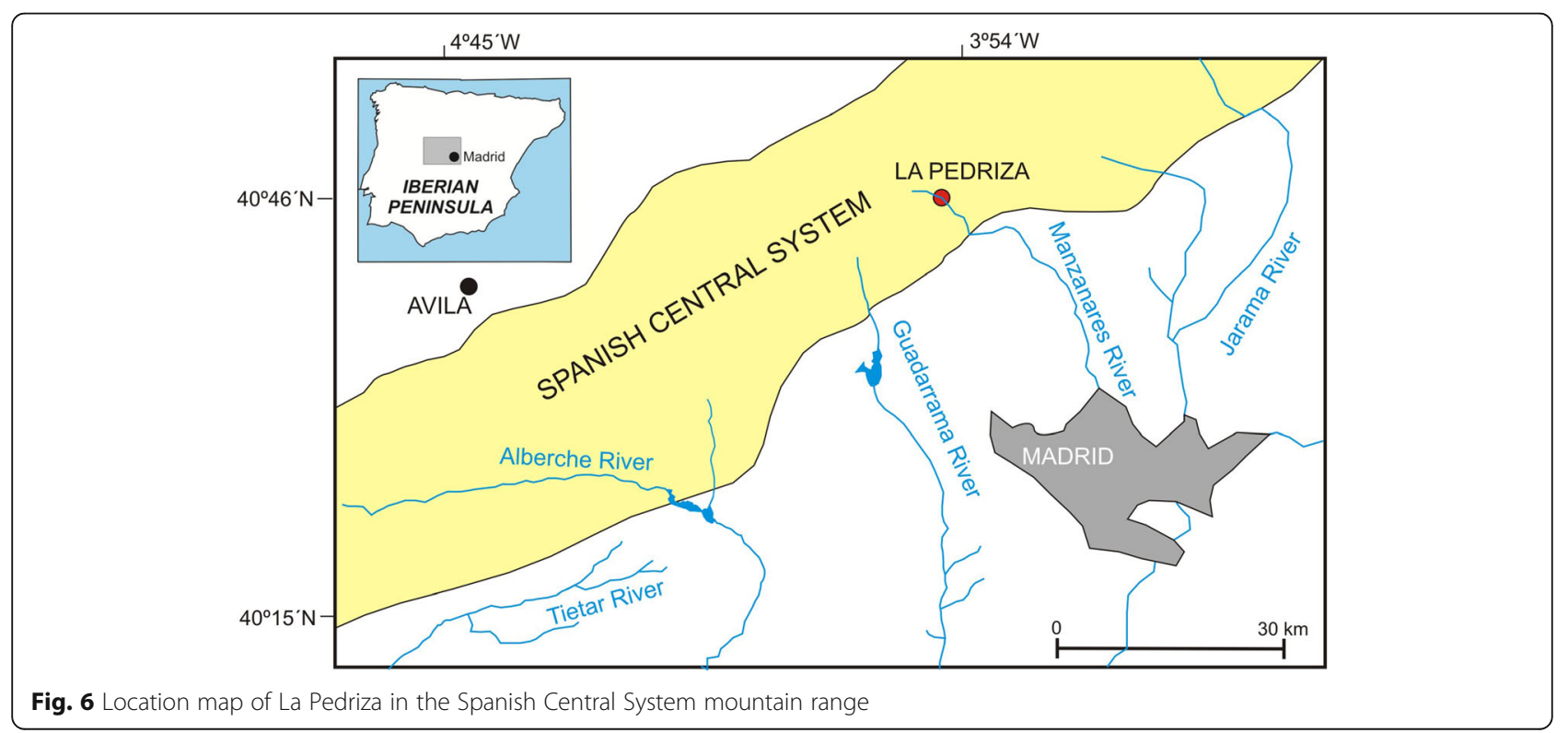




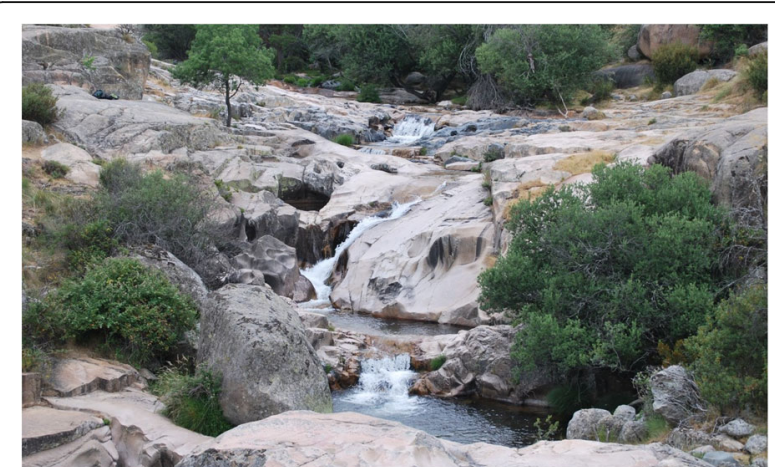

Fig. 7 Test area at the upper Manzanares river in La Pedriza

Other flood events are related to snowmelt during late spring and intense convective storms during autumn. The flood-peak discharge with a 500 year recurrence $\left(\mathrm{Q}_{500}=145 \mathrm{~m}^{3} \cdot \mathrm{s}^{-1}\right)$ exceeds around six times the annual peak discharge $\left(\mathrm{Q}_{2}=24 \mathrm{~m}^{3} \cdot \mathrm{s}^{-1}\right)$ at the study site (Ortega et al. 2014).

The outcropping microdioritic dikes generate a variety of large-scale sculpted features, such as waterfalls, pools, potholes and furrows. Figure 8 shows a 2D hydraulic modelling at the study site including results of principal variables like flow depth and velocity, and flow direction. This model was obtained using Iber, a free 2D hydrodynamic modelling software (Bladé et al. 2014). Surface topography was obtained with a 3D mesh from a DEM ( $0.25 \mathrm{~m}$ pixel size), which was created by interpolation of UAV digital photogrammetry point cloud data $(0.05 \mathrm{~m}$ pixel size). This model shows the complex macro-scale flow patterns generated by a highly-variable topography.

Small-scale SfM was also carried out at the site from 64 photographs of a $2.47 \mathrm{~m}^{2}(1.58 \times 1.56 \mathrm{~m})$ area where reference axes were determined using six coded targets. Then, a point cloud of 6,612,543 points was generated with Agisoft Photoscan Edition (1.1.6) software, which translated into a $1,333,581$ faces model, with a size between 1 and $0.1 \mathrm{~mm}$. Software manipulation of the 3D mesh was be used to obtain profiles of the model (Fig. 9).

In addition to this, small-scale crests, troughs, submillimetre pits and scratch marks were observed at the outcropping microdioritic dikes (Fig. 10). A TraceIT optical rugosimeter was therefore used to obtain a 3D model and roughness parameters of these surface marks.

Both the stoss slope and the lee slope were measured keeping Y-axis oriented towards the north. Two oriented surface scans were therefore obtained (Fig. 11). The scan on the stoss slope (Fig. 11a) shows asymmetrical impact scratches elongated in a northeast-southwest direction. On the lee slope (Fig. 11b), round pits with diameters less than $0.9 \mathrm{~mm}$ and depth less than $0.38 \mathrm{~mm}$ that could be related to cavitation are observed. Roughness parameters calculated on these surfaces (Table 1) show, there is much more variability on roughness indices between $\mathrm{E}-\mathrm{W}$ and N-S axis on the stoss slope than on the lee slope, because of the more isotropic shape of cavitation pits. The dominant E-W component of the impact scratches on the stoss slope results in a higher roughness

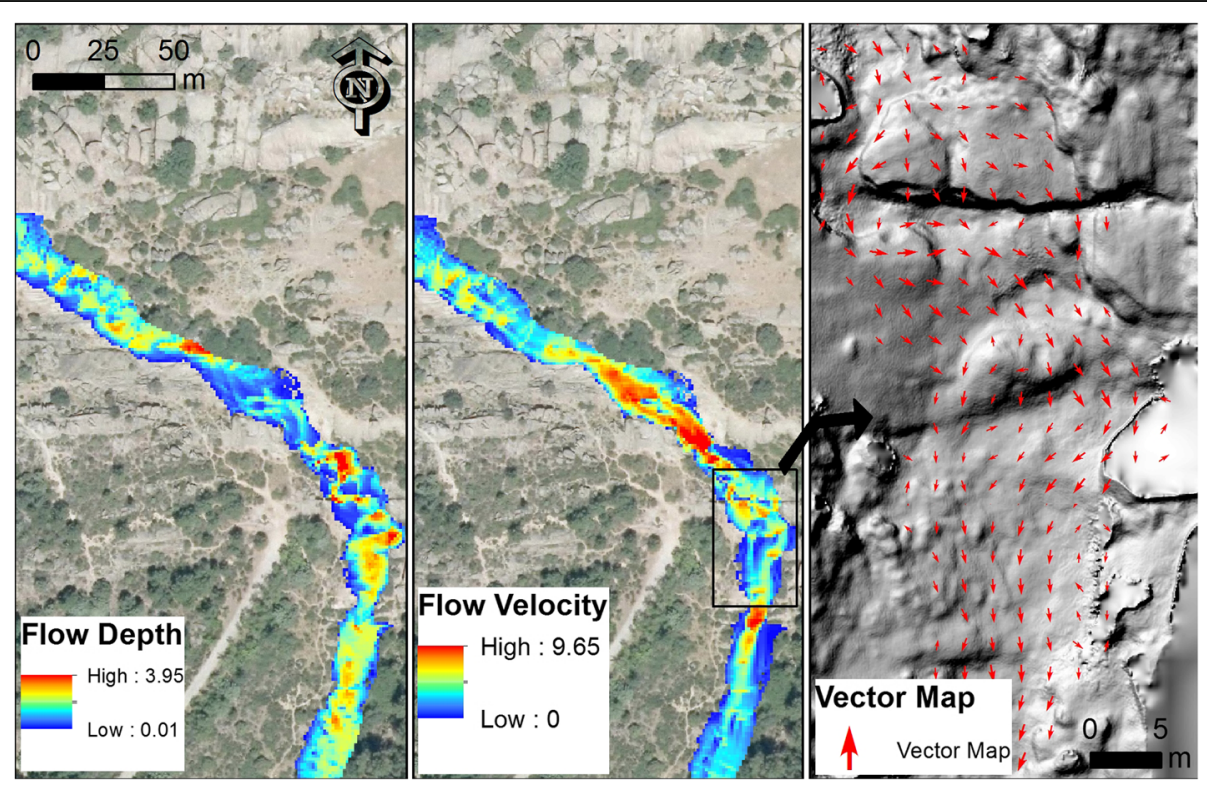

Fig. 8 Results of the 2D hydraulic model developed in the area of La Pedriza. This model refers to the variables flow depth (left) and velocity (centre). Noticeable variations observed in both variables are the result of large-scale roughness of bedrock and may be responsible for the development of large-scale bedrock forms, such as pools, potholes and grooves. The image on the right represents flow directions vectors, which could be correlated to occurrence of the abovementioned forms 
A

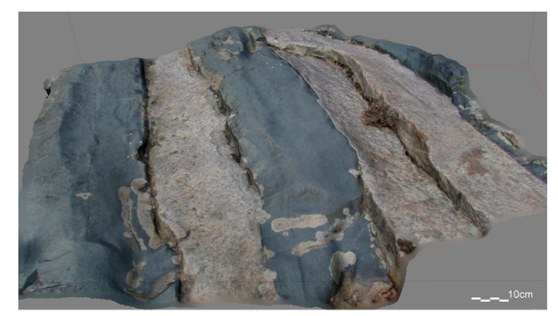

B

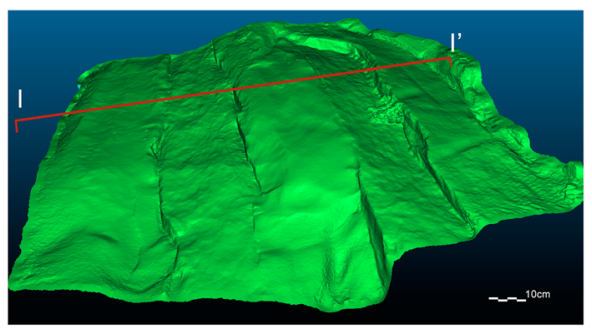

\section{C}

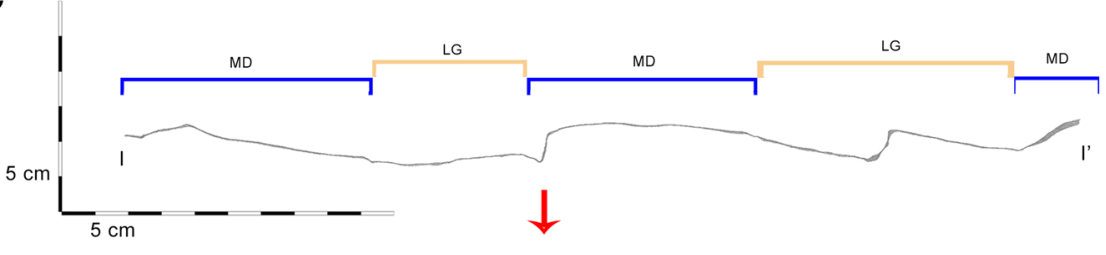

D

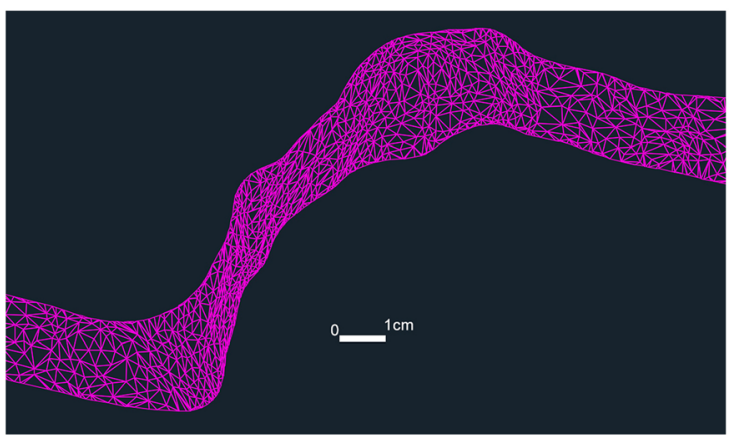

Fig. 9 Textured point cloud 3D model (a). Polygonal mesh model of the same area with profile line I-I' marked (b). I-I' profile where Leucogranite $(\mathrm{LG})$ and Microdiorite (MD) areas are marked (c). Detail of mesh in the area of the profile marked with an arrow (d). Microdiorite dykes run east to west

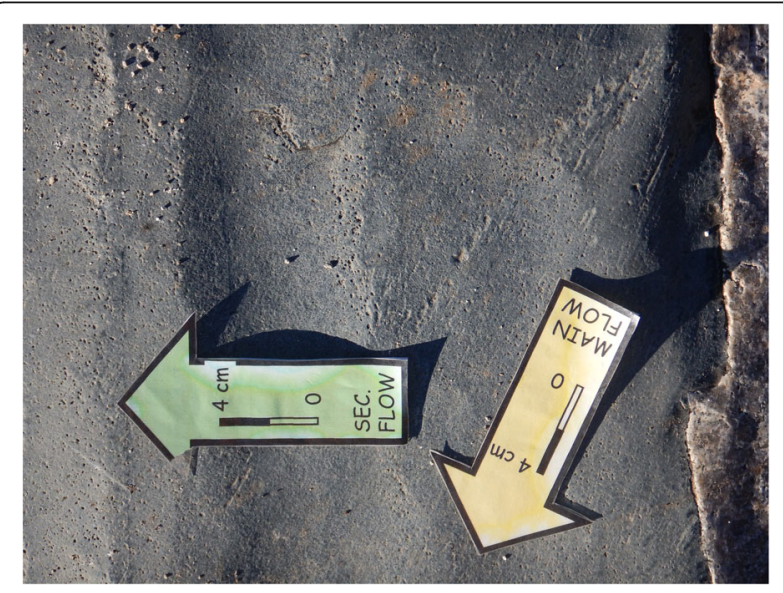

Fig. 10 Microdiorite dyke with a series of crests and troughs. Scratches are superimposed to stoss slopes and steep, concave, lee slopes show pits. North is on the top right of the image in the N-S direction than in the E-W direction and than in the lee slope.

These preliminary results will be discussed in relation to the information obtained from previously discussed techniques to obtain DEM and on the basis of its potential to be used to obtain information on flow directions as well as from cavitation, abrasion or plucking processes in bedrock rivers. In addition, based on how this technique reveals these, otherwise invisible, microforms, it will be discussed how a new layer of microscale information enriches the geomorphological heritage values of this site. Either establishing it as a model of trans-scale geomorphological processes or as an educational resource, by giving to the public new tools to understand the geomorphological processes behind landscape at several scales.

\section{Discussion: integrating high-resolution and ultra- detailed topographic data in a bedrock river}

Bedrock rivers are a fine example to demonstrate the interconnection between small-scale features and 


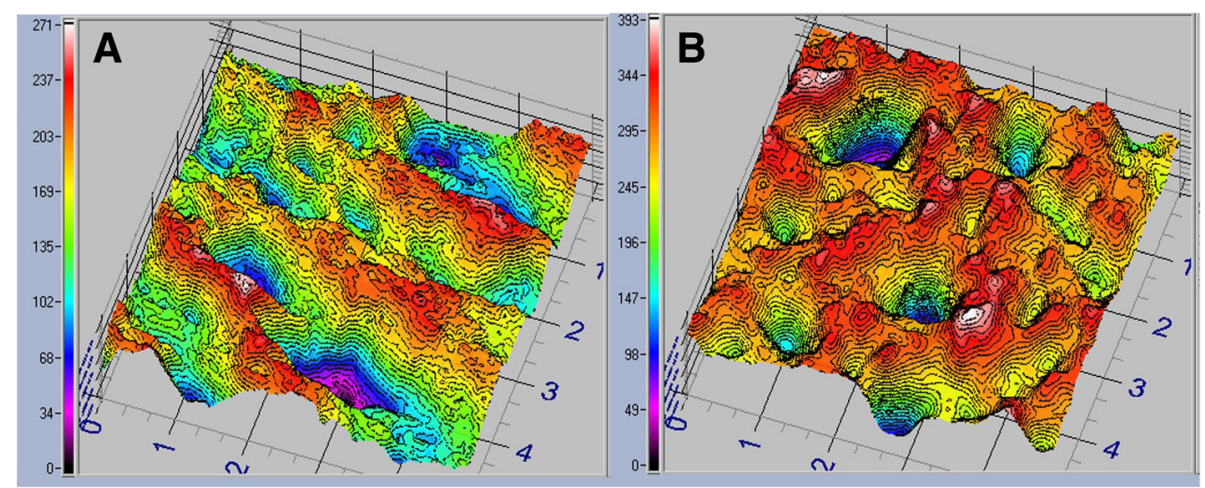

Fig. 11 Surface scans of a $5 \times 5 \mathrm{~mm}$ area on crest slopes. The stoss slopes (a) show elongated scratches corresponding to the main northeastsouthwest flow direction, which superimposes to the secondary flow forming the crests and troughs. Pits of various sizes on lee slopes (b) are formed by the action of the secondary flow forming crests and troughs

large-scale behaviour in natural complex systems. Erosional processes dominate the morphology of most bedrock channels and to be able to understand erosion fully, the scale factor needs to be taken into account. Erosion ranges from small spatial scale (micro-scale, millimetre to centimetre) with erosional characteristics as abrasion, flacking or plucking (small size grains), meso-scale (centimetre to metre) with selective erosion that produce potholes, grooves, knickpoints, inner-channels and other meso-features and finally macro-scale (metre to kilometre) with morphologies at reach, basin-scale (Wohl 1998).

Several studies have dealt with the influence of small-scale features and processes on large-scale ones as previously cited Anton et al. (2015) and Beer et al. (2017), as well as more recent works by Ortega-Becerril et al. (2017b) and the synthesis work of Scott and Wohl (2018). However, the level of sub-millimetre detail obtained by means of a microrugosimeter is unprecedented in bedrock river geomorphology.

Large-scale techniques, such as ALS or airborne photogrammetry are useful for the understanding of large sections of bedrock rivers. An example of this in the upper Manzanares river area is shown in Fig. 8. In this model, the interaction of the river system with its surroundings and the impact of discharge on how flow directions may change can be ascertained. Each flow stage, or "shaping flow", will be related to different erosional levels, from small-scale processes, such as

Table 1 Roughness parameters for both N-S and E-W axes obtained from surface scans of stoss and lee slopes

\begin{tabular}{|c|c|c|c|c|c|c|}
\hline & \multicolumn{3}{|l|}{ E-W axis } & \multicolumn{3}{|l|}{$\mathrm{N}-\mathrm{S}$ axis } \\
\hline & $\mathrm{Ra}(\mu \mathrm{m})$ & $\mathrm{Rq}(\mu \mathrm{m})$ & $\mathrm{Rz}(\mu \mathrm{m})$ & $\mathrm{Ra}(\mu \mathrm{m})$ & $\mathrm{Rq}(\mu \mathrm{m})$ & $\operatorname{Rz}(\mu \mathrm{m})$ \\
\hline Stoss slope & $6 \pm 1$ & $8 \pm 2$ & $26 \pm 5$ & $9 \pm 2$ & $12 \pm 2$ & $36 \pm 7$ \\
\hline Lee slope & $9 \pm 2$ & $11 \pm 3$ & $33 \pm 8$ & $8 \pm 2$ & $10 \pm 3$ & $28 \pm 6$ \\
\hline
\end{tabular}

cavitation or micro-abrasion through medium-scale plucking or, if flow increases, large-scale erosional tool removal, highlighting the interconnection of scales in erosion. ALS LiDAR models may be used to assert the influence of large-scale lithological changes; however, this technique is not detailed enough to understand small-scale flow diversions and the influence of localised lithological changes on river dynamics.

The shaping flow could imply erosion at various flow levels instead of dominant discharge that imply that general river landscape is controlled by a certain flow level. Some studies have examined the idea of a dominant discharge that might shape bedrock channels. Although literature on this topic in alluvial channels is extensive (e.g. Lamb and Fonstad 2010; Venditti et al. 2014; Beer et al. 2017), we still are in the early stages of understanding whether the concept of a dominant discharge/shaping flows could be applied to bedrock channels. This is particularly important, as small-scale flows (and therefore small-scale erosion) should be considered an agent in bedrock river evolution. One of the keys to understand the channel morphology in bedrock rivers is to use new tools to measure channel erosion rates by ordinary flows instead the classic idea of larger flows generating catastrophic changes. These flows have a lot of energy and potential for geomorphic change, but the recurrence period is also large. Further detailed studies should be carried out to test this hypothesis because abrasion of hard bedrock might not be significantly effective until flow depths and sediment loads are quite high, although abrasion generates extremely small-scale features. On the contrary, the observed pitting in the lee side of pseudo-ripples seems to be due to the cavitation process that has been formed during low water flows and has been able to develop bedrock erosion. This is inferred from the 
observed direction divergence between low (N186E) and high flow (N125E) under flood conditions, as well as the location of pitting, just downstream from pseudo-ripples crests. This observation diverges from general knowledge (e.g. Hancock et al. 1998) that indicated high flows and speeds as necessary for the existence of cavitation. In using the microrugosimeter, one of the key findings is indeed the occurrence of pitting related to low flow levels that lightly cover the pseudo-ripples. Nevertheless, this process is still under-researched according to Hancock et al. (1998) and this point should still be considered a hypothesis.

A higher level of detail is obtained with SfM models in the example area (Fig. 6). This digital model shows the surface effects of localised lithological changes, such as the occurrence of microdiorite dykes. This technique has proved useful for the observation of mesoscale forms and surface differences between two adjacent lithologies: hard, apparently smooth, microdiorite standing slightly proud from host leucogranite, which shows block removal. At this scale, it is noticeable the existence of local flow diversions, which in turn establish themselves as different "shaping flows", indicated by centimetre-scale surface marks.

Figure 12 summarises the transition between DEM scales from ALS LiDAR to the microrugosimeter. While the flow model obtained from a large-scale DEM indicates a dominant northwest-southeast flow for this area, the DEM obtained with SfM reveals a series of crests and troughs at small scale that means flow separation and cavitation (identified by small-scale pits). These features are smaller and different in origin than upstream facing convex surfaces (UFCS defined by Richardson and Carling 2005; Beer et al. 2017) and indicate a secondary north-south local flow direction. Crests and troughs operate at two different scales (Fig. 6C): decimetric crests that extend throughout leucogranite and microdiorite, and centimetric crests confined to microdiorite dykes.

Optical microrugosimeter confirms the trans-scale complexity allowing a more detailed observation of the surface of microdiorite centimetric crests and troughs. Stoss slopes show millimetric scratch marks (Figs. 11A and 12C), which reflect small-scale predominant large-scale northwest-southeast flow, while lee slopes show a totally different pattern that could be related to cavitation associated with the lower intensity north-south secondary "shaping flow". These marks, invisible to the naked eye, highlight once more the complex patterns of flow found in bedrock rivers. The variability of small-scale features (Fig. 13) in these crests and troughs (sharp-crested hummocky forms in the classification of Richardson and Carling (2005)) reflect what could be called "fluvial micro-systems" within the large-scale system.
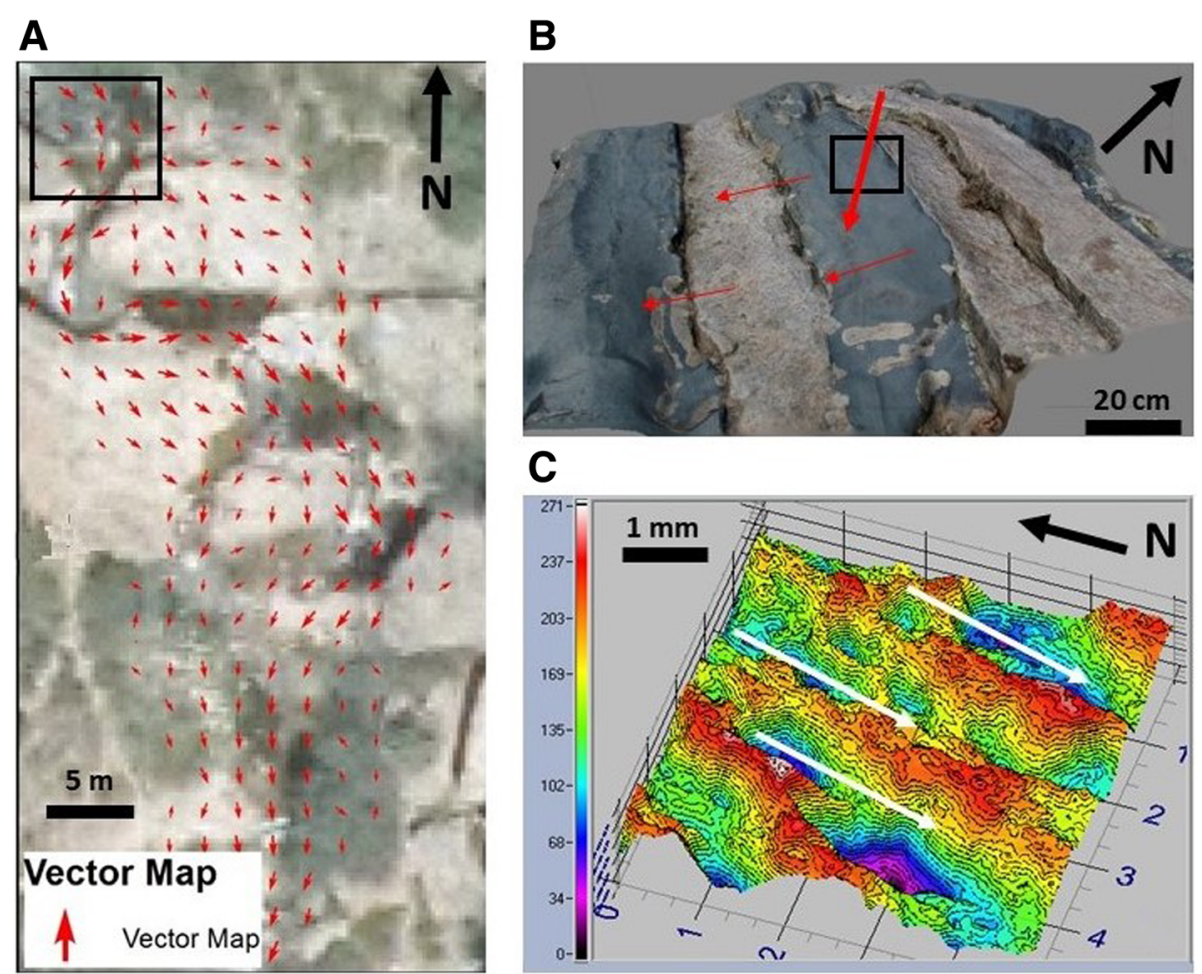

Fig. 12 An example of how different morphometric techniques operate indicating flow directions (red arrows, white arrows in c) at different scales. Macroscale DEM (a) and mesoscale DEM (b) from SfM and $5 \times 5 \mathrm{~mm}$ microscan obtained with optical microrugosimeter on the stoss slope of a microdiorite crest 


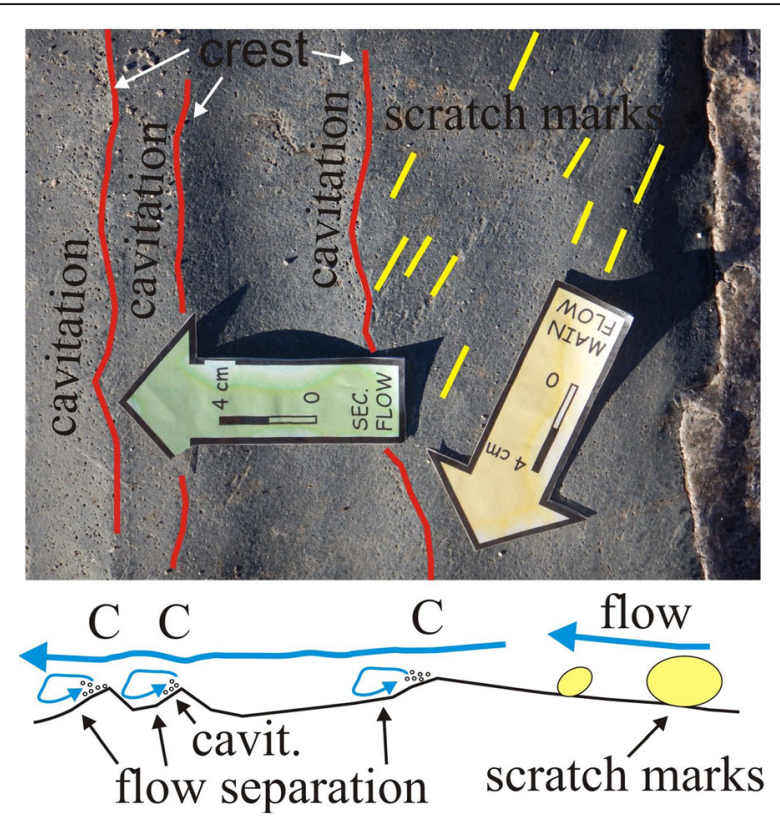

Fig. 13 An interpretation of the image shown in Fig. 10. Crests and troughs in a microdiorite dyke. Scratch marks superimposed on gentle convex stoss slopes form following the direction of the main flow. Pseudo-ripples crests develop perpendicularly to a secondary flow. The secondary flow could generate cavitation on steep concave lee slopes, forming pits as a consequence of the small crystal size and higher weatherability of microdiorite

Meso-scale SfM images showed microdiorite dykes standing slightly proud of host granite with an apparently smoother surface as a result of higher resistance to erosion (Schmidt hammer values of 62 for microdiorite vs. 55 for granite, according to previous works (Ortega et al. 2014, 2017b)). However, small-scale surface scans with optical rugosimeter show a rough surface (indeed rougher in microdiorite ( $\mathrm{Rz}$ values from 15 to $35 \mu \mathrm{m}$ ) than in granite (Rz values ranging from 5 to $20 \mu \mathrm{m}$ )), which may be a reflection of its higher weatherability. This is a fine example of how variations of lithology and "energy transfer", in the above-discussed sense given by Hall et al. (2012), may influence sculpted forms even in an area of a few centimetres as it does at larger scales (Ortega-Becerril et al. 2017b).

The highly detailed observation scale offered by the microrugosimeter has also direct and indirect implications for considerations on geodiversity. For example, the case study used to demonstrate this technique is listed as a geosite mainly on petrological and geochemical criteria because of the intruding microdiorite dykes. However, the impact these dykes generate on meso- and particularly micro-scale erosion processes, and therefore its richness in relation to geomorphological values, could go unnoticed (in the sense of Cayla et al. 2012) without the advancement on DEM acquisition offered by the microrugosimeter.
Brilha (2016) proposed the assessment of scientific, educational and touristic values for the inventory of geosites. Scientific knowledge, didactic and interpretative potential are three of the items in these categories. Detailed DEMs, such as those presented for rugosimeter, not only increase an improvement of scientific knowledge and trans-scale issues, but also open up new possibilities in terms of the didactic and interpretative potential of the site, enrichening its value and the perception of its geodiversity by the public.

\section{Conclusions}

This paper highlights the importance of bedrock rivers as an outstanding feature within geodiversity and how the evolution of methods for downscaling morphological analysis adds new layers to their value. As Ferrer et al. (2017) state, spatial scales introduce complexity into geomorphology, but one also can say it introduces richness. Bedrock rivers epitomise the relationship between scales in geomorphological research and their richness because the diversity of small-scale features illustrates how the complex relation of energy transfer processes at the small-scale impacts on landscapes. The technology improvements for obtaining DEMs has allowed quantifying topography at an improved range of scales "to see which was formerly invisible" (Viles 2016).

While the value of LiDAR (mainly ALS) and airborne photogrammetry cannot be diminished in understanding the large-scale components of bedrock rivers systems, SfM offered easy and cheap solutions to obtain DEMs for meso-scale analysis. Although technically possible using LiDAR, SfM's lower cost facilitates adding time to the three spatial dimensions $\mathrm{X}, \mathrm{Y}$ and $\mathrm{Z}$ by generating several DEMs over time, creating then a four-dimensional (4D) space.

The use of optical microrugosimeters in geomorphological research represents a big development as it facilitates drastically micromorphometric analysis and offers the possibility of 3D analysis of microforms in a way a series of profiles obtained through contact profilometers could not allow. All of this means the use of microrugosimeters are particularly useful to study bedrock rivers as they allow us to detect changes in bedrock incision rates, which usually operate in very small-scale from $0.01 \mathrm{~mm} / \mathrm{yr}$. Microrugosimeters also allow a detailed water flow direction assessment from morphological analysis, a key point in steep and complex bedrock rivers.

In addition to this, microrugosimeter reveal microforms, otherwise invisible in the concept Cayla et al. (2012) introduced for large geomorphological structures. This tool, therefore, opens the scope for improving the knowledge we have on trans-scale issues in bedrock rivers as well as it opens a new layer of information to 
enrich the geomorphological heritage values of a site by increasing its didactic and interpretative potential and the perception of geodiversity by the public.

All this said, the multiscale understanding of complex systems is of great importance not only to interpret the evolution of a natural system, but also to manage the human-nature interactions and the sense of value of geodiversity.

\section{Abbreviations}

ALB: Airbone LiDAR bathymetry; ALS: Airborne laser scanner; DEM: Digital elevation model; LiDAR: Light detection and ranging; MLS: Mobile laser scanner; SfM: Structure from motion; TLS: Terrestrial laser scanner; UAV: Unmanned aerial vehicle (drone)

\section{Acknowledgements}

We thank Geohazards InSAR Modelling group for assistance on airborne scan used on large-scale DEM models. MG wishes to thank Japan Geosciences Union for support on presenting this research in session M-ISO7 "Conservation of natural geosites and cultural heritage: weathering process and damage assessment" at the JpGU general meeting 2017 held at Tokyo, Japan. In addition, MG is indebted to Dr. Chiaki Oguchi for facilitating the attendance to the JpGU general meeting and her ongoing professional and personal support. Finally, the authors would like to thank M Hogan, DN Scott and other, anonymous reviewer whose comments helped to improve the manuscript.

\section{Funding}

This work was supported by Geomateriales 2 (S2013/MIT-2914) and Top Heritage (P2018/NMT-4372) programmes from the Regional Government of Madrid (Spain).

\section{Availability of data and materials}

Data sharing is not applicable to this article as no datasets were generated or analysed during the current study.

\section{Authors' contributions}

MG and JAO conceived, designed and supervised the study. JG carried out and interpreted LiDAR models, LL did so with SFM analysis and RF with microroughness. JAO and MG undertook the general parts of the overview and interpretation. All authors contributed to drafting the manuscript. All authors read and approved the final manuscript.

\section{Competing interests}

The authors declare that they have no competing interests.

\section{Publisher's Note}

Springer Nature remains neutral with regard to jurisdictional claims in published maps and institutional affiliations.

\section{Author details}

'Department of Geology and Geochemistry, Universidad Autónoma de Madrid, 28049 Madrid, Spain. ${ }^{2}$ Department of Geodynamics, Stratigraphy and Palaeontology, Universidad Complutense de Madrid, 28040 Madrid, Spain ${ }^{3}$ Instituto de Geociencias (CSIC, UCM), 28040 Madrid, Spain. ${ }^{4}$ Artfabrik, 28029 Madrid, Spain.

Received: 28 March 2018 Accepted: 1 March 2019

Published online: 25 March 2019

\section{References}

Aggett GR, Wilson JP (2009) Creating and coupling a high-resolution DTM with a 1-D hydraulic model in a GIS for scenario-based assessment of avulsion hazard in a gravel-bed river. Geomorphology 113:21-34. https://doi.org/10. 1016/j.geomorph.2009.06.034

Alho P, Hyyppä H, Hyyppä J (2009a) Consequence of DTM precision for flood hazard mapping: a case study in SW Finland. Nordic J Surveying Real Estate Res 6(1):21-39
Alho P, Kukko A, Hyyppä H, Kaartinen H, Hyyppä J, Jaakkola A (2009b) Application of boat-based laser scanning for river survey. Earth Surf Process Landf 34: 1831-1838. https://doi.org/10.1002/esp.1879

Almagro A (2010) Veintidós años de experiencia de fotogrametría arquitectónica en la Escuela de Estudios Árabes, CSIC IPCE 2010. Ministry of Culture, Spain. pp 26-45

Anton L, Mather AE, Stokes M, Muñoz-Martín A, De Vicente G (2015) Exceptional river gorge formation from unexceptional floods. Nat Commun 6:7963. https://doi.org/10.1038/ncomms8963

Aydin G, Karakurt I, Aydiner K (2011) An investigation on surface roughness of granite machined by abrasive waterjet. Bull Mater Sci 34(4):985-992. https:// doi.org/10.1007/s12034-011-0226-x

Baggs Sargood M, Cohen TJ, Thompson CJ, Croke J (2015) Hitting rock bottom: morphological responses of bedrock-confined streams to a catastrophic flood. Earth Surf Dynam 3:265-279. https://doi.org/10.5194/esurf-3-265-2015

Baltsavias E (1999a) A comparison between photogrammetry and laser scanning. ISPRS J Photogramm Remote Sens 54:83-94. https://doi.org/10.1016/S09242716(99)00014-3

Baltsavias E (1999b) Airborne laser scanning: basic relations and formulas. ISPRS J Photogramm Remote Sens 54:199-214. https://doi.org/10.1016/S09242716(99)00015-5

Beer AR, Turowski JM, Kirchner JW (2017) Spatial patterns of erosion in a bedrock gorge. JGeophys Res Earth Surf 122:1-24. https://doi.org/10.1002/ 2016JF003850

Bergey EA (2006) Measuring the surface roughness of stream stones. Hydrobiologia (2006) 563:247-252. doi: https://doi.org/10.1007/s10750-006-0016-4

Bernaldo de Quiros C (1923) La Pedriza del Real de Manzanares. Comisaría Regia del Turismo y Cultura Artística, Madrid

Birdseye CH (1940) Stereoscopic phototopographic mapping. Ann Assoc Am Geogr 30:1-24

Bladé E, Cea L, Corestein G, Escolano E, Puertas J, Vázquez-Cendón E, Dolz J, Coll A (2014) Iber: herramienta de simulación numérica del flujo en ríos. Revista Internacional de Métodos Numéricos para Cálculo y Diseño en Ingeniería 30(1):1-10

Brilha J (2016) Inventory and quantitative assessment of geosites and geodiversity sites: a review. Geoheritage 8(2):119-134. https://doi.org/10. 1007/s12371-014-0139-3

Bryan PG, Clowes M (1997) Surveying Stonehenge by photogrammetry. Photogramm Rec 15(89):739-751. https://doi.org/10.1111/0031-868X.00082

Burrough PA (1986) Methods of interpolation. In: Principles of geographical information systems for land resources assessment. OUP, Oxford, pp 147-166

Carey CJ, Brown TG, Challis KC, Howard AJ, Cooper L (2006) Predictive modelling of multiperiod geoarchaeological resources at a river confluence: a case study from the Trent-Soar, UK. Archaeol Prospect 13:241-250. https://doi.org/ 10.1002/arp.295

Casas A, Benito G, Thorndycraft VR, Rico M (2006) The topographic data source of digital terrain models as a key element in the accuracy of hydraulic flood modelling. Earth Surf Process Landf 31(4):444-456. https://doi.org/10.1002/ esp. 1278

Cavalli M, Tarolli P, Marchi L, Fontana GD (2008) The effectiveness of airborne LiDAR data in the recognition of channel-bed morphology. Catena 73(3): 249-260. https://doi.org/10.1016/j.catena.2007.11.001

Cayla N (2014) An overview of new technologies applied to the management of geoheritage. Geoheritage 6(2):91-102. https://doi.org/10.1007/s12371-014-0113-0

Cayla N, Hoblea F, Biot V, Delamette M, Guyomard A (2012) De l'invisibilite des geomorphosites a la revelation geopatrimoniale. Geocarrefour 87(3-4):171-186. https://doi.org/10.4000/geocarrefour.8817

Chandler J (1999) Effective application of automated digital photogrammetry for geomorphological research. Earth Surf Process Landf 24:51-63. https://doi. org/10.1002/(SICl) 1096-9837(199901)24:1<51::AID-ESP948>3.0.CO;2-H

Chandler JH, Buckley S (2016) Structure from motion (SFM) photogrammetry vs terrestrial laser scanning. In: Carpenter MB, Keane CM (eds) Geoscience Handbook 2016: AGl data sheets, 5th edn. American Geosciences Institute, Alexandria Section 20.1

Charlton ME, Large ARG, Fuller IC (2003) Application of airborne LiDAR in river environments: the river coquet, Northhumberland, UK. Earth Surf Process Landf 28(3):299-306. https://doi.org/10.1002/esp.482

Cobby DM, Mason DC, Horritt MS, Bates PD (2003) Two dimensional hydraulic flood modelling using a finite-element mesh decomposed according to vegetation and topographic features derived from airborne scanning laser altimetry. Hydrol Process 17(10):1979-2000. https://doi.org/10.1002/hyp.1201 
Cook A, Merwade V (2009) Effect of topographic data, geometric configuration and modeling approach on flood inundation mapping. J Hydrol 377:131142. https://doi.org/10.1016/j.jhydrol.2009.08.015

Coratza P, Hoblea F (2018) The specifities of geomorphological heritage. In: Reynard E, Brilha J (eds) Geoheritage assessment, protection and management. Elsevier, pp 87-106. https://doi.org/10.1016/B978-0-12-8095317.00005-8

Dąbski M (2015) Application of the Handysurf E-35B electronic profilometer for the study of weathering micro-relief in glacier forelands in SE Iceland. Acta Geol Pol 65(3):389-401. https://doi.org/10.1515/agp-2015-0018

Dąbski M, Tittenbrun A (2013) Time-dependant surface deterioration of glacially abraded basaltic boulders deposited by Fláajökull, SE Iceland. Jökull 63:55-70

Davis WM (1899) The geographical cycle. Geogr J 14:481-504

De Prado, C. (1864) Descripción física y geológica de la provincia de Madrid. 1975 facsimile edition of the original published in 1864. Publicaciones especiales Colegio de Ingenieros de Caminos, Canales y Puertos, Madrid

De Reu J, De Smedt P, Herremans D, Van Meirvenne M, Laloo P, De Clercq W (2014) On introducing an image-based 3D reconstruction method in archaeological excavation practice. J Archaeol Sci 41:251-262

De Reu J, Plets G, Verhoeven G, De Smedt P, Bats M, Cherretté B, De Maeyer W, Deconynck J, Herremans D, Laloo P, Van Meirvenne M, De Clercq W (2013) Towards a three-dimensional cost-effective registration of the archaeological heritage. J Archaeol Sci 40(2):1108-1121. https://doi.org/10.1016/j.jas.2012.08.040

Domínguez Pérez C, Martínez González J, Castañeda Cerecero L, Mena Cruz A (2017) Drones, fotogrametría y arqueología en México. Principios y ejemplos Arqueología 52:187-215

Domínguez-Villar D, Arteaga C, García-Giménez R, Smith EA, de Pedraza J (2008) Diurnal and seasonal water variations of temperature, $\mathrm{pH}$, redox potential and conductivity in gnammas (weathering pits): implications for chemical weathering. Catena 72:37-48. https://doi.org/10.1016/j.catena.2007.03.018

Dudley N (ed) (2008) Guidelines for applying protected area management categories. IUCN, Gland

Eardley AJ (1942) Aerial photographs: their use and interpretation. Harper and Brothers, New York

Entwistle NS, Fuller IC (2009) Terrestrial laser scanning to derive the surface grain size facies character of gravel bars. In: Heritage GL, Large ARG (eds) Laser scanning for the environmental sciences. Wiley, Chichester, pp 102-114

Esteve J, Zhao YL, Maté-González MÁ, Gomez-Heras M, Peng J (2018) A new high-resolution 3-D quantitative method for analysing small morphological features: an example using a Cambrian trilobite. Scientific Reports 12(8(1)): 2868. https://doi.org/10.1038/s41598-018-21088-4

Etienne $S$ (2002) The role of biological weathering in periglacial areas: a study of weathering rinds in south Iceland. Geomorphology 47(1):75-86. https://doi. org/10.1016/S0169-555X(02)00142-3

Fernández-Lozano J, Gutiérrez-Alonso G (2017) The Alejico carboniferous forest: a 3D-terrestrial and UAV-assisted photogrammetric model for geologic heritage preservation. Geoheritage 9(2):163-173. https://doi.org/10.1007/ s12371-016-0193-0

Ferrer V, Errea P, Alonso E, Gomez-Gutierrez A, Nadal-Romero E (2017) A multiscale approach to assess geomorphological processes in a semiarid badland area (Ebro Depression, Spain). Cuadernos de Investigación Geográfica 43(1):41-62

Finnegan NJ, Dietrich WE (2011) Episodic bedrock strath terrace formation due to meander migration and cutoff. Geology 39(2):143-146 https://doi.org/10. 1130/G31716.1

Fort R, Álvarez de Buergo M, Vázquez-Calvo C, Gómez-Villalba LS (2013) Análisis de la microrugosidad mediante técnicas portátiles: aplicaciones y casos de estudio en patrimonio. Ciencia y Arte IV. Ministerio de Educación y Cultura, Madrid. 198-216

Fort R, Vázquez-Calvo C, Chapa T, Martínez-Navarrete Ml, Belén M (2012) An analytical study of Iberian Iron Age stone sculptures and their surface marks. Archaeometry 55(3):391-406. https://doi.org/10.1111/j.1475-4754.2012.00686.x

Fraser CS, Cronk S (2009) A hybrid measurement approach for close-range photogrammetry. ISPRS J Photogramm Remote Sens 64(3):328-333. https:// doi.org/10.1016/j.isprsjprs.2008.09.009

Freire-Lista DM, Fort R (2017) Exfoliation microcracks in building granite. Implications for anisotropy. Eng Geol 220:85-93. https://doi.org/10.1016/j. enggeo.2017.01.027

Freire-Lista DM, Gomez-Villalba LS, Fort R (2015) Microcracking of granite feldspar during thermal artificial processes. Periodico di Mineralogia 84:519-537. https://doi.org/10.2451/2015PM0029
French JR (2003) Airborne LiDAR in support of geomorphological and hydraulic modelling. Earth Surf Process Landf 28(3):321-335. https://doi.org/10.1002/ esp.484

Fujii Y, Shogakib T, Miyakawa M (2018) Photogrammetric documentation and non-invasive investigation of a stone dry dock, the Yokosuka arsenal dry dock no. 1, Japan. Eng Geol 234:122-131. https://doi.org/10.1016/j.enggeo. 2017.12.022

García-Rodríguez M, Gómez-Heras M, Álvarez de Buergo M, Fort R, Aroztegui J (2015) Polygonal cracking associated to vertical and subvertical fracture surfaces in granite (La Pedriza del Manzanares, Spain): considerations for a morphological classification. J Iber Geol 41(3):365-383. https://doi.org/10. 5209/rev_JIGE.2015.v41.n3.48860

García-Rodríguez M, Sánchez-Jiménez A, Murciano A, Pérez-Uz B, MartínCereceda M (2017) Influencia de la temperatura sobre la asimetría de pilancones en ambiente granítico. Aplicación de un modelo de regresión lineal. BOL Bol Soc Geol Mex 69(2):479-494

Garrote J, Díez-Herrero A, Bodoque JM, Perucha MA, Mayer PL, and Génova M (2018) Flood hazard management in public mountain recreation areas vs. ungauged fluvial basins. Case study of the Caldera de Taburiente National Park, Canary Islands (Spain). Geosciences 8(1): 6. doi:https://doi.org/10.3390/ geosciences 8010006

Garzón-Heydt G, Ortega-Becerril JA, Duran-Valsero JJ (2012) Los ríos en roca de la península ibérica. Un ejemplo de elevada geodiversidad. In: González Diez A. (Coord.) Avances de la geomorfología en España (2010-2012). PUbliCan, Santander, pp 39-42

Ghiraldi L, Giordano E, Perotti L, Giardino M (2014) Digital tools for collection, promotion and visualisation of geoscientific data: case study of Seguret valley (Piemonte, NW Italy). Geoheritage 6: 103-112. https://doi.org/10.1007/ s12371-014-0115-y

Gomes-Pereira LM, Wicherson RJ (1999) Suitability of laser data for deriving geographical information: a case study in the context of management of fluvial zones. ISPRS J Photogramm Remote Sens 54(2-3):105-114. https://doi. org/10.1016/S0924-2716(99)00007-6

Gomez-Heras M, Lopez-Gonzalez L, García-Morales S, Fort R, Álvarez de Buergo M (2014) Integrating non-destructive techniques with photogrammetry 3D models for the development of geographic information systems in heritage structures. In: Rogerio-Candelera MA (ed) Science, technology and cultural heritage. Taylor \& Francis Group, London, pp 429-434

Gomez-Heras M, Smith BJ, Fort R (2008) Influence of surface heterogeneities of building granite on its thermal response and its potential for the generation of thermoclasty. Environ Geol 56(3-4):547-560. https://doi.org/10.1007/ s00254-008-1356-3

Grissom CA, Charola AE, Washowiak MJ (2000) Measuring surface roughness on stone; back to basics. Stud Conserv 45:73-84. https://doi.org/10.2307/1506665

Hall K, Thorn C, Sumner P (2012) On the persistence of 'weathering'. Geomorphology 149-150:1-10. https://doi.org/10.1016/j.geomorph.2011.12.024

Hancock GS, Anderson RS, Whipple KX (1998) Beyond power: bedrock river incision process and form. Geophysical Monograph Series 107:35-60. https:// doi.org/10.1029/GM107p0035

Hayakawa YS, Oguchi T, Lin Z (2008) Comparison of new and existing global digital elevation models: ASTER G-DEM and SRTM-3. Geophys Res Lett 35(17): L17404. https://doi.org/10.1029/2008GL035036

Heritage G, Hetherington D (2007) Towards a protocol for laser scanning in fluvial geomorphology. Earth Surf Process Landf 32(1):66-74. https://doi.org/ 10.1002/esp.1375

Heritage GL, Milan DJ (2009) Terrestrial laser scanning of grain roughness in a gravel-bed river. Geomorphology 113(1-2):4-11. https://doi.org/10.1016/j. geomorph.2009.03.021

Hoblea F, Delannoy J-J, Jaillet S, Ployon E, Sadier B (2014) Digital tools for managing and promoting karst geosites in southeast France. Geoheritage 6: 113-127. https://doi.org/10.1007/s12371-014-0112-1

Hodge R, Brasington J, Richards K (2009a) Analysing laser-scanned digital terrain models of gravel bed surfaces: linking morphology to sediment transport processes and hydraulics. Sedimentology 56(7):2024-2043. https://doi.org/10. 1111/j.1365-3091.2009.01068.x

Hodge R, Brasington J, Richards K (2009b) In situ characterization of grain-scale fluvial morphology using terrestrial laser scanning. Earth Surf Process Landf 34(7):954-968. https://doi.org/10.1002/esp.1780

Hodgson E and Bresnahan P (2004) Accuracy of airborne lidar-derived elevation: empirical assessment and error budget. Photogramm Eng Rem S 70(3): 331339. doi: https://doi.org/10.14358/PERS.70.3.331 
Hodgson ME, Jensen JR, Schmidt L, Schill S, Davis B (2003) An evaluation of lidarand IFSAR-derived digital elevation models in leaf-on conditions with USGS level 1 and level 2 DEMs. Remote Sens Environ 84(2):295-308. https://doi. org/10.1016/S0034-4257(02)00114-1

Hohenthal J, Alho P, Hyyppä J, Hyyppä H (2011) Laser scanning applications in fluvial studies. Prog Phys Geogr 35(6):782-809. https:/doi.org/10.1177/0309133311414605

Hubbard B, Glasser NF (2005) Field techniques in glaciolology and glacial geomorphology. Wiley, Chichester

Hudson BJ (2013) Waterfalls, science and aesthetics. J Cult Geog 30(3):356-379. https://doi.org/10.1080/08873631.2013.828482

Inoue T, Izumi N, Shimizu Y, Parker G (2014) Interaction among alluvial cover, bed roughness, and incision rate in purely bedrock and alluvial-bedrock channel. J Geophys Res-Earth 119(10):2123-2146. https://doi.org/10.1002/2014JF003133

Inoue T, Yamaguchi S, Nelson JM (2017) The effect of wet-dry weathering on the rate of bedrock river channel erosion by saltating gravel. Geomorphology 285:152-161. https://doi.org/10.1016/j.geomorph.2017.02.018

Jones A, Brewer PA, Johnstone E, Macklin MG (2007) High-resolution interpretative geomorphological mapping of river valley environments using airborne LiDAR data. Earth Surf Process Landf 32(10):1574-1592. https://doi.org/10.1002/esp.1505

Jordá F, Navarro S, Pérez A, Cachero R, López D, Lerma JL (2011) Close range photogrammetry and terrestrial laser scanning: high resolution texturized $3 \mathrm{D}$ model of the Chapel of The Kings in the Palencia Cathedral as a case study. In: Pavelka K (ed) Proceedings of the XXIIIrd International CIPA Symposium. CTU-CIPA, Prague

Kasvi E, Vaaja M, Alho P, Hyyppä H, Hyyppä J, Kaartinen H, Kukko A (2012) Morphological changes on meander point bars associated with flow structure at different discharges. Earth Surf Process Landf 38(6):577-590. https://doi.org/10.1002/esp.3303

Lamb MP, Finnegan NJ, Scheingross JS, Sklar LS (2015) New insights into the mechanics of fluvial bedrock erosion through flume experiments and theory. Geomorphology 244:33-55. https://doi.org/10.1016/j.geomorph.2015.03.003

Lamb MP, Fonstad MA (2010) Rapid formation of a modern bedrock canyon by a single flood event. Nat Geosci 3(7):477. https://doi.org/10.1038/ngeo894

Lane SN (2000) The measurement of river channel morphology using digital photogrammetry. Photogramm Rec 16(96):937-961. https://doi.org/10.1111/ 0031-868X.00159

Lane SN, Chandler JH, Richards KS (1998) Landform monitoring, modelling and analysis: landform in geomorphological research. In: Lane SN, Richards KS, Chandler JH (eds) Landform monitoring. Modelling and Analysis. Wiley, Chichester, pp 1-18

Laussedat A (1854) Mémoire sur l'emploi de la chamber Claire dans les reconnaissances topographiques. Mémorial de l'Officier du Génie. 16. MalletBachelier, Paris

Lin Z, Oguchi T (2002) Applications of photogrammetry in geomorphology: a review. Journal of Geography (Chigaku Zasshi) 111(1):1-15. https://doi.org/10 5026/jgeography. 111.1

Lohani B, Mason DC (2001) Application of airborne scanning laser altimetry to the study of tidal channel geomorphology. ISPRS J Photogramm Remote Sens 56(2):100-120. https://doi.org/10.1016/S0924-2716(01)00041-7

López-Arce P, Varas-Muriel MJ, Fernandez-Revuelta B, Alvarez de Buergo M, Fort R, Pérez-Soba C (2010) Artificial weathering of Spanish granites subjected to salt crystallization tests: surface roughness quantification. Catena 83(2-3):170 185. https://doi.org/10.1016/j.catena.2010.08.009

Lopez-Gonzalez L, Otero-Ortiz de Cosca R, Gomez-Heras M, García-Morales S (2016) A 4D GIS methodology to study variations in evaporation points on a heritage building. Environ Earth Sci 75(14):1113. https://doi.org/10.1007/ s12665-016-5907-8

Marks K, Bates P (2000) Integration of high-resolution topographic data with floodplain flow models. Hydrol Process 14(11-12):2109-2122. https://doi.org/ 10.1002/1099-1085(20000815/30)14:11/12<2109::AID-HYP58>3.0.CO;2-1

Mason DC, Cobby DM, Horritt MS, Bates PD (2003) Floodplain friction parameterization in two-dimensional river flood models using vegetation heights derived from airborne scanning laser altimetry. Hydrol Process 17(9): 1711-1732. https://doi.org/10.1002/hyp.1270

McCarroll D (1992) A new instrument and techniques for the field measurement of rock surface roughness. Z Geomorphol 36:69-79

McCarthy J (2014) Multi-image photogrammetry as a practical tool for cultura heritage survey and community engagement. J Archaeol Sci 43:175-185. https://doi.org/10.1016/j.jas.2014.01.010

Micheletti N, Chandler JH, Lane SN (2015) Investigating the geomorphological potential of freely available and accessible structure-from-motion photogrammetry using a smartphone. Earth Surf Process Landf 40(4):473486. https://doi.org/10.1002/esp.3648

Milan DJ (2009) Terrestrial laser scan-derived topographic and roughness data for hydraulic modelling of gravelbed rivers. In: Heritage GL, Large ARG (eds) Laser scanning for the environmental sciences. Wiley, Chichester, pp 133-146

Milan DJ, Heritage GL, Hetherington D (2007) Application of a 3D laser scanner in the assessment of erosion and deposition volumes and channel change in a proglacial river. Earth Surf Process Landf 32(11):1657-1674. https://doi.org/10. 1002/esp.1592

Moropoulou A, Delegou ET, Vlahakis V, Karaviti E (2007) Digital processing of SEM images for the assessment of cleaning interventions on Pentelic marble surfaces. Mater Character 58(11-12):1063-1069. https://doi.org/10.1016/j. matchar.2007.04.021

Németh K, Casadevall T, Moufti MR, Marti J (2017) Volcanic geoheritage. Geoheritage 9: 251-254. doi: https://doi.org/10.1007/s12371-017-0257-9

Notebaert B, Verstraeten G, Govers G, Poesen J (2009) Qualitative and quantitative applications of LiDAR imagery in fluvial geomorphology. Earth Surf Process Landf 34(2):217-231. https://doi.org/10.1002/esp.1705

Oguchi T, Wasklewicz T, Hayakawa YS (2013) Remote data in fluvia geomorphology: characteristics and applications. In: Shroder JF (ed) Treatise on geomorphology, vol 9. Academic Press, San Diego, pp 711-729

Omer CR, Nelson J, Zundel AK (2003) Impact of varied data resolution on hydraulic modeling and floodplain delineation. J Am Water Resour As 39(2): 467-475. https://doi.org/10.1111/j.1752-1688.2003.tb04399.x

Ortega JA, Gomez-Heras M, Perez-López R, Wohl E (2014) Multiscale structural and lithologic controls in the development of stream potholes on granite bedrock rivers. Geomorphology 204:588-598. https://doi.org/10.1016/j. geomorph.2013.09.005

Ortega-Becerril JA, Jorge-Coronado A, Garzón G, Wohl E (2017a) Sobrarbe Geopark: an example of highly diverse bedrock rivers. Geoheritage 9(4):533548. https://doi.org/10.1007/s12371-016-0207-y

Ortega-Becerril J, Gomez-Heras M, Fort R, Wohl E (2017b) How does anisotropy in bedrock river granitic outcrops influence pothole genesis and development. Earth Surf Process Landf 42(6):956-968. https://doi.org/10.1002/esp.4054

Otero EM (2004) Giner y Cossío en el verano de 1883. Memoria de una excursión inolvidable. Boletín de la Institución Libre de Enseñanza 55:9-38

Overton IC, Siggins A, Gallant JC, Penton D, Byrne G (2009) Flood modelling and vegetation mapping in large river systems. In: Heritage GL, Large ARG (eds) Laser scanning for the environmental sciences. Wiley, Chichester, pp 220-244

Panizza M (2001) Geomorphosites: concepts, methods and example of geomorphological survey. Chin Sci Bull 46(Suppl 1):4-6. https://doi.org/10. 1007/BF03187227

Panizza M, Piacente S (2008) Geomorphology and cultural heritage in coastal environments. Geogr Fis Dinam Quat 31:205-210

Pedraza J, Carrasco MR, Domínguez-Villar D (2014) Geomorphology of La Pedriza granitic massif, Guadarrama range. In: Gutiérrez F, Gutiérrez M (eds) Landscapes and landforms of Spain. Springer, Amsterdam, pp 71-81

Pelletier JD, Sweeney KE, Roering JJ, Finnegan NJ (2014) Controls on the geometry of potholes in bedrock channels. Geophys Res Lett 42(3):797-803. https://doi.org/10.1002/2014GL062900

Pena C (2016) Sorolla tierra adentro (cat. de la exposición). Fundación Museo Sorolla-Palacios y Museos, Madrid

Prieto B, Silva B, Aira N, Álvarez L (2006) Toward a definition of a bioreceptivity index for granitic rocks: perception of the change in appearance of the rock. Int Biodeterior Biodegrad 58(3-4):150-154. https://doi.org/10.1016/j.ibiod.2006.06.015

Ravanel L, Bodin X, Deline P (2014) Using terrestrial laser scanning for the recognition and promotion of high-alpine geomorphosites. Geoheritage 6(2): 129-140. https://doi.org/10.1007/s12371-014-0104-1

Ravanel L, Deline P, Bodin X (2015) LIDAR-helped recognition and promotion of high-alpine geomorphosites. In: Lollino G, Giordan D, Marunteanu C, Christaras B, Yoshinori I, Margottini C (eds) Engineering geology for society and territory, Preservation of cultural heritage, vol 8. Springer, Cham, pp 249252. https://doi.org/10.1007/978-3-319-09408-3_42

Reusser L, Bierman P (2007) Accuracy assessment of LiDAR-derived DEMs of bedrock river channels: Holtwood Gorge, Susquehanna River. Geophys Res Lett 34(23): L23S06. doi: https://doi.org/10.1029/2007GL031329

Ribeiro RP, Paraguassú AB, Moreiras STF (2011) Factors affecting slab surface roughness of siliceous dimension stones. Bull Eng Geol Environ 70:625-631. https://doi.org/10.1007/s10064-010-0345-4

Richardson K, Carling P (2005) A typology of sculpted forms in open bedrock channels (Vol. 392). Geological Society of America 
Saito H, Uchiyama S, Hayakawa YS, Obanawa H (2018) Landslides triggered by an earthquake and heavy rainfalls at Aso volcano, Japan, detected by UAS and SfM-MVS photogrammetry. Progress in Earth and Planetary Science 5:15. https://doi.org/10.1186/s40645-018-0169-6

Santos I, Henriques R, Mariano G, Pereira DI (2018) Methodologies to represent and promote the geoheritage using unmanned aerial vehicles, multimedia technologies, and augmented reality. Geoheritage 10(2):143-155. https://doi. org/10.1007/s12371-018-0305-0

Santos PMD, Júlio ENBS (2013) A state-of-the-art review on roughness quantification methods for concrete surfaces. Constr Build Mater 38:912-923. https://doi.org/10.1016/j.conbuildmat.2012.09.045

Scott DN, Brogan DJ, Lininger KB, Schook DM, Daugherty EE, Sparacino MS, Patton Al (2016) Evaluating survey instruments and methods in a steep channel. Geomorphology 273:236-243. https://doi.org/10.1016/j.geomorph.2016.08.020

Scott DN, Wohl EE (2018) Bedrock fracture influences on geomorphic process and form across process, domains and scales. Earth Surf Process Landf. https://doi.org/10.1002/esp.4473

Sklar LS, Dietrich WE (2004) A mechanistic model for river incision into bedrock by saltating bed load. Water Resour Res 40(6)

Sousa LMO, Gonçalves BMM (2013) Differences in the quality of polishing between sound and weathered granites. Environ Earth Sci 69:1347-1359. https://doi.org/10.1007/s12665-012-2035-y

Springer GS, Tooth S, Wohl EE (2005) Dynamics of pothole growth as defined by field data and geometrical description. J Geophys Res-Earth 110:F04010. https://doi.org/10.1029/2005JF000321

Straatsma MW, Baptist M (2008) Floodplain roughness parameterization using airborne laser scanning and spectral remote sensing. Remote Sens Environ 112(3):1062-1080. https://doi.org/10.1016/j.rse.2007.07.012

Sweeney KE, Roering JJ (2017) Rapid fluvial incision of a late Holocene lava flow: insights from LiDAR, alluvial stratigraphy, and numerical modeling. GSA Bull 129(3-4):500-512. https://doi.org/10.1130/B31537.1

Thoma DP, Gupta SC, Bauer ME, Kirchoff CE (2005) Airborne laser scanning for riverbank erosion assessment. Remote Sens Environ 95(4):493-501. https:// doi.org/10.1016/j.rse.2005.01.012

Tinkler K, Wohl E (1998). A primer on bedrock channels. In: Rivers over rock (K. Tinkler and E. Wohl, eds.). AGU monograph, 107, 1-18

Vázquez P, Luque A, Alonso FJ, Grossi CM (2013) Surface changes on crystalline stones due to salt crystallisation. Environ Earth Sci 69:1237-1248. https://doi. org/10.1007/s12665-012-2003-6

Vazquez-Calvo C, Álvarez de Buergo M, Fort R, Varas MJ (2012) The measurement of surface roughness to determine the suitability of different methods for stone cleaning. J Geophys Eng 9:108-117. https://doi.org/10.1088/1742-2132/9/4/S108

Velázquez VF, Portela VDA, Sobrinho JMA, Guedes ACM, Letsch MAJSP (2016) Fluvial erosion characterisation in the Juqueriquerê River channel, Caraguatatuba, Brazil. Earth Science Research 5:105 https:/doi.org/10.5539/esr.v5n2p105

Venditti JG, Rennie CD, Bomhof J, Bradley RW, Little M, Church M (2014) Flow in bedrock canyons. Nature 513(7519):534 https://doi.org/10.1038/nature13779

Viles HA (2001) Scale issues in weathering studies. Geomorphology 41(1):63-72. https://doi.org/10.1016/S0169-555X(01)00104-0

Viles HA (2012) Microbial geomorphology: a neglected link between life and landscape. Geomorphology 157-158:6-16. https://doi.org/10.1016/j. geomorph.2011.03.021

Viles HA (2016) Technology and geomorphology: are improvements in data collection techniques transforming geomorphic science? Geomorphology 270:121-133. https://doi.org/10.1016/j.geomorph.2016.07.011

Wang Y, Liang X, Flener C, Kukko A, Kaartinen H, Kurkela M, Vaaja M, Hyyppä H, Alho P (2013) 3D modeling of coarse fluvial sediments based on mobile laser scanning data. Remote Sens 5(9):4571-4592. https://doi.org/10.3390/ rs5094571

Westoby MJ, Brasington J, Glasser NF, Hambrey MJ, Reynolds JM (2012) 'Structure-from-motion' photogrammetry: a low-cost, effective tool for geoscience applications. Geomorphology 179:300-314. https://doi.org/10. 1016/j.geomorph.2012.08.021

Whipple KX, DiBiase RA, Crosby BT (2013) Bedrock rivers. In: J. Shroder (Ed). Treatise on geomorphology 2: 550-573. Academic Press, San Diego

Wohl E, Bierman PR, Montgomery DR (2017) Earth's dynamic surface: a perspective on the past 50 years in geomorphology. The web of geological sciences: advances, impacts, and interactions II. Geological Society of America Special Paper 523. doi: https://doi.org/10.1130/2016.2523(01)

Wohl EE (1998) Bedrock channel morphology in relation to erosional processes. Geophysical Monograph Series 107:133-151

\section{Submit your manuscript to a SpringerOpen ${ }^{\circ}$ journal and benefit from:}

- Convenient online submission

- Rigorous peer review

- Open access: articles freely available online

- High visibility within the field

- Retaining the copyright to your article

Submit your next manuscript at $\boldsymbol{\nabla}$ springeropen.com 